\title{
Recent advancements in the use of biochar for cementitious applications: A review
}

\author{
Banjo A. Akinyemi ${ }^{\text {a, * }}$, Adeyemi Adesina ${ }^{b}$ \\ ${ }^{a}$ Structures and Building Materials Unit, Department of Agricultural and Biosystems Engineering, Landmark University, Omuaran, Nigeria \\ ${ }^{\mathrm{b}}$ Department of Civil and Environmental Engineering, University of Windsor, Canada
}

\section{A R T I C L E I N F O}

\section{Keywords:}

Biochar

Agro-residues

Admixture

Cement

Materials

Properties

\begin{abstract}
A B S T R A C T
With increasing population and rising demands for improved built environment, there is an expected increase in greenhouse gas emission from the construction industry. Carbon dioxide emission levels are fast approaching a tipping point which could lead to irreversible climate change. The earth's capability to neutralise the $\mathrm{CO}_{2}$ emissions through the natural carbon cycle has been overstretched. Therefore it is imperative to adopt technologies that are able to capture and sequester $\mathrm{CO}_{2}$ in order to cancel out their release from industrial activities such as the construction and building industry. This is important so that cement-based material productions' carbon footprint can be reduced drastically for a positive change to take place in the climate. Biochar holds great promise as an effective $\mathrm{CO}_{2}$ sorptive material in cement-based applications relatively similar to its conventional use for soil amendment. Actually, fragmented researches on biochar as an admixture in cementitious materials have been conducted. Based on this logic, this review placed enormous emphasis on collating information from recent studies on biochars from agro-sources used as an admixture in cement-based applications. Similarly, the review gave up-to-date knowledge about the sources of the biomass and the production processes. Conclusively, the positive effects of biochar for carbon sequestration on some properties of the various cementitious applications were highlighted.
\end{abstract}

\section{Introduction}

Greenhouse gases composed of carbon dioxide $\left(\mathrm{CO}_{2}\right)$ among other deleterious gases are generated in large quantities by different humaninduced processes [1]. These anthropogenic processes range from the use of fossil fuels for energy generation to several production processes such as the production of Portland cement. One key material that is utilised for construction purposes is Portland cement which studies have shown to contribute around $8 \%$ to worldwide $\mathrm{CO}_{2}$ emissions [2,3]. Cement-based applications have evolved over the years into different building materials including but not limited to paste, mortar and concrete that are currently being utilised because they are durable, economical and possess high strength properties [4-6]. With millions of tonnes of cementitious materials being produced and used annually worldwide, it has become imperative to consider new alternatives that are green and have a low carbon signature [7-10]. Studies have proposed the use of supplementary cementitious materials (SCMs) [11-16], recycling of construction and demolition wastes
$[17,18]$ and industrial wastes $[19,20]$ as major ways of mitigating the negative effects of the carbon footprint of these cementitious materials on the environment. These recycled and waste materials can be used as partial to total replacement of the binder and/or aggregate components in cementitious composites. The use of SCMs as partial replacement of Portland cement will result in a significant reduction in the embodied carbon and energy of cementitious composites while creating an effective waste management avenue $[168,169]$. The use of recycled materials from various industries will also result in reduction of the negative impact of cementitious composites as these recycled materials can be incorporated as aggregates. For example, Akinyemi et al. [170] were able to incorporate rice husk as a sustainable alternative aggregate in cementitious composites. In general, a low carbon cementitious composite can be obtained by incorporating materials with low embodied carbon materials such as waste and recycled materials. Most of the aforementioned alternative materials have proven track records of outstanding performances as Portland cement replacement when used for construction purposes. Recent studies and

\footnotetext{
* Corresponding author.

E-mail address: bantonbows@gmail.com (B.A. Akinyemi).
} 
discoveries have shown that another important unconventional material to fill this gap is the adoption of biochar as a natural admixture. It could be used in cementitious applications most importantly because of its capability to sequester atmospheric $\mathrm{CO}_{2}$ being an eco-friendly adsorbent material [21-26]. The use of biochar has been found to result in approximately $900 \mathrm{~kg} \mathrm{CO}_{2}$ reduction in the net greenhouse gas emissions due to the storage and carbon capture of the biomass used in producing the biochar [171]. Also, the use of biochar as low as $1 \%$ replacement of the fine aggregate in cementitious composites has been found to improve the compressive strength by approximately $10 \%$ [172]. Similarly, biochar has been found to be a sustainable and effective admixture to improve the immobilization of noxious contaminants in sediment products $[173,174]$. Hence, biochar is a sustainable material that can be incorporated into cementitious composites to improve performance.

\section{Definition of biochar and distinction from other variants}

Biochar can be explained to be the product of an organic substance that had undergone combustion under very minimal oxygen levels resulting in a carbon-rich material [27-29]. It is used mostly for soil remediation and amendment to improve the health of the soil and reduce the greenhouse gas emission effect on it [30-32]. Biochar, activated carbon and charcoal are fundamentally like fraternal twins which possess lots of similarities but are different from each other. A common trait among them is that they are all products of biomass thermochemical processes [33,34] while the basic difference among them is their end-use or the intended applications. Biochar is produced in the same way as charcoal; however, the end-use is either for the soil amendment or as an absorbent material [35]. As such, the production process is adjusted to different sets of properties and tagged as biochar, but if the goal is to utilise it for fuel, it is called charcoal [36]. Nonetheless, biochar can be produced from various processes such as pyrolysis, carbonization, microwave-assisted carbonation, steam gasification, etc. Activated carbon is usually utilised as a sorbent to get rid of contaminants from liquids and gases. This was further explained by Marsh and Reinoso [37] that it could be called a sorption contaminant material without further demands pertaining to the production sustainability and the quality of the carbon after its utilization.

\section{Agricultural sources for biochar production}

Studies on agricultural feedstocks as sources for the production of biochar are in-exhaustible. However, some of these studies are outlined in Table 1.

\section{Basic production processes of biochar from agro-sources}

Biochar is produced by converting the biomass into char using several methods that include fast pyrolysis, slow pyrolysis and gasification.

\subsection{Fast pyrolysis}

It is a process involving the application of heat flux to feedstock particles in the absence of oxygen, resulting in extreme heating conditions. It could also be defined as the disintegration of complex molecules that are large into small molecules using high temperatures without oxygen [69,70]. The range is usually between 400 and $800{ }^{\circ} \mathrm{C}$ with short residence time (less than $2 \mathrm{~min}$ ) in the absence of oxygen resulting in degrading of the feedstock into gases, vapours and biochars [71]. The heating rate of $10{ }^{\circ} \mathrm{C} / \mathrm{s}$ is used in fast pyrolysis in comparison with slow pyrolysis. It is a sophisticated system in which the process is controlled carefully to give many yields [72,73]. Short
Table 1

Some selected sources for biomass production.

\begin{tabular}{|c|c|c|c|}
\hline $\mathrm{S} / \mathrm{N}$ & Agro-biomass & Production process & References \\
\hline 1 & $\begin{array}{l}\text { Sawdust } \\
\text { waste }\end{array}$ & Pyrolysis & {$[38,39]$} \\
\hline 2. & Bamboo & Pyrolysis & {$[40,41]$} \\
\hline 3 & Rice husk & Pyrolysis & [42-44] \\
\hline 4 & $\begin{array}{l}\text { Groundnut } \\
\text { shell waste }\end{array}$ & carbonization, pyrolysis & {$[45,46]$} \\
\hline 5. & Peanut shell & Pyrolysis & {$[47,48]$} \\
\hline 6 & $\begin{array}{l}\text { Tomato plant } \\
\text { waste }\end{array}$ & Pyrolysis & [49] \\
\hline 7 & Castor plant & Pyrolysis & {$[50]$} \\
\hline 8 & $\begin{array}{l}\text { Bagasse/sugar } \\
\text { cane }\end{array}$ & $\begin{array}{l}\text { pyrolysis, slow pyrolysis, microwave-assisted } \\
\text { carbonation, vacuum pyrolysis }\end{array}$ & [51-54] \\
\hline 9 & Food waste & pyrolysis, gasification & {$[55,56]$} \\
\hline 10. & Cow dung & fast pyrolysis, pyrolysis & {$[57,58]$} \\
\hline 11. & $\begin{array}{l}\text { Poultry } \\
\text { manure }\end{array}$ & slow pyrolysis, fast pyrolysis & {$[59,60]$} \\
\hline 12 & Corn cob & Pyrolysis & {$[61,62]$} \\
\hline 13 & Sludge & slow pyrolysis, microwave pyrolysis & {$[63,64]$} \\
\hline 14 & Grass & pyrolysis, steam gasification & {$[65,66]$} \\
\hline 15 & Straw & $\begin{array}{l}\text { slow pyrolysis, carbonization at low } \\
\text { temperature }\end{array}$ & {$[67,68]$} \\
\hline
\end{tabular}

residence time leads to incomplete lignin depolymerisation because of haphazard inter-reactions of macromolecule of the lignin and the bond cleavage, however, prolonged residence time can lead to secondary cracks within the primary yield properties [74].

\subsection{Slow pyrolysis}

This is the traditional method of producing charcoal which has been in existence for thousands of years [75]. In slow pyrolysis, the feedstock is most times heated up to $500{ }^{\circ} \mathrm{C}$ in the absence of oxygen at a heating rate of $10{ }^{\circ} \mathrm{C} / \mathrm{min}$ [76]. Slow pyrolysis does not require fine biomass particle size which is lesser than $1 \mathrm{~mm}$, unlike the fast pyrolysis. The end-products are dependent majorly on total time for reaction, rate of heating, final temperature and particle size of biomass [77]. The main products of slow pyrolysis are char and tar. By the end of the primary reactions, re-polymerization reactions usually take place.

\subsection{Gasification}

This method involves the conversion of carbonaceous substances into a gas fuel at a very high temperature without oxygen. The gas fuel comprises hydrogen, carbon dioxide, carbon monoxide and methane. It requires a medium for the reaction to take place such as steam, air, oxygen, and/or a mixture of these media [78]. The three by-products of gasification are char, syngas and heat [79]. The two main types of gasification are the steam and hydrothermal gasification. The reaction of steam with carbonaceous biomass or carbon-rich substances to produce syngas is known as steam gasification [80]. Drying, pyrolysis, reduction and combustion reactions are the four main processes that take place during steam-gasification. The liberation of moisture takes place during the liberation phase; removal of hydrocarbons, tar and volatile compounds such as carbon monoxide and carbon dioxide in form of gases occurs during pyrolysis; some reactions between pyrolysis and dry products take place during reduction. Char decomposition to form more gaseous materials finally takes place during the combustion phase [81,82]. Hydro-thermal gasification is another type of feedstock gasification using hot and compressed water. This system utilizes sub-critical liquid water or supercritical state water to gasify majorly wet biomass [83]. There is a very fast degradation of the polymer structure of the biomass during the fast pyrolysis, as a result of this, the reaction rate of polymerization to 
form coke and tar is reduced. Therefore, a high gas yield at very low temperatures is produced [84].

To conclude this segment, the most common carbonation procedure for getting a high yield of biochar is through pyrolysis, but the char produced from gasification most times does not fulfil the required standard to be termed as biochar.

\section{Adoption of biochar in studies involving cementitious materials}

The use of biochar as a material in cement-based applications is an emerging area of study with few authors already working on different approaches. Different feedstocks with various production systems were adopted in these studies with a singular goal of utilising the biochar to improve some properties of the final product. Some were done to enhance the quality of the biochar-modified cement composite against environmental or hazardous elements. The adoption of carbonation as a method of carbon sequestration in cement-based materials has been restricted to those without steel reinforcement owing to the possibility of corrosion $[85,86]$. Such a method is best suited for utilization in thin-shelled precast porous cementitious materials for minimal and negligible penetration of $\mathrm{CO}_{2}$ into such systems [87]. The inclusion of carbon-rich biochar particles from an agro-based feedstock for carbon sequestration in cement-based materials could possibly have a better and more inclusive application in comparison with carbonation. The main reason for this position is that, based on some of the reviewed studies, biochar has some major promising attributes for its adoption as an admixture in cementitious materials. These include enhanced chemical stability, low conductivity, limited flammability [88] as an internal curing agent [89] and because of its carbon capture and storage potential.

\subsection{Chemical stability of biochars in cementitious materials}

Some chemical reactions that attack cement-based materials are alkali-silica reactions and reactions with chloride and carbonation lead to the deterioration of the cement matrix. However, it is desired that there should be chemical stability so that no deleterious products are produced from reactions of any type of admixtures with other contents of the concrete matrix. Such chemical stability can possibly be achieved through the addition of biochars into cementitious materials for various construction applications. The chemical stability of biochar depends heavily on the stability of fixed carbon as well as the existence and volume of groups of oxygen within the chemical composition [90]. Some findings have proposed that better chemical stability of biochar is accomplished when fast pyrolysis at a temperature of $800{ }^{\circ} \mathrm{C}$ is used. This is because at low pyrolysis with a temperature of $350{ }^{\circ} \mathrm{C}$, low quantities of carbon nutrients having low sorptive capabilities that are needed for sequestration are produced [91,92]. But at higher temperatures, higher carbon contents and aromaticity of the feedstock are produced accompanied by increased surface area needed for sorption while oxygen and hydrogen volume are reduced which are the reactive zones [93,94]. Such reduction in the reactive spots leads to better chemical stability and the produced biochar is not likely to develop destructive chemical reactions when mixed with cementitious materials. A study by Kambo et al. [95] revealed that the use of biochar reduces alkali and alkaline base contents in soil amendment through biomass particle pulverization and thermal pretreatment. These help to enhance the fluidization process during combustion and also reduce the biomass polymer structure. Studies and analyses could be conducted on this area by applying it to cementbased materials to possibly reduce the influence of chemical reactions affecting the strength development.

\subsection{Low thermal conductivity}

It is well understood that the thermal conductivity of most cementbased materials is determined by the size, shape and orientation of the pores $[96,97]$. For biochar, three different classes of pores have been identified, these are micro-pores, mesopores and macro-pores each with various sizes, shapes and orientations which affect their performances differently [98]. The numerous pores in biochar have diverse trends based on the temperature of biochar production. It has been reported that the volume of the pores is usually on the increase when the higher temperature of pyrolysis is used [99]. The normal thermal conductivity of conventional concrete is between the ranges of $0.62-3.3 \mathrm{~W} / \mathrm{mK}$ [100] which is far higher than the reported results of some studies involving biochar as an admixture. On the addition of a higher mixing ratio of biochar into a cement-based material by Lee et al. [101], a thermal conductivity of $0.138-0.155 \mathrm{~W} / \mathrm{mK}$ was obtained which is $49.68-67.21 \%$ lesser than the conventional cement bio-composite used as the control. In another study by Yun et al. [102], a decrease in thermal conductivity up to $0.192 \mathrm{~W} / \mathrm{mK}$ was achieved when 1 and $2 \%$ wts of biochar were added to the cement composite. This was achievable because the pores in the added biochar were able to disrupt the thermal bridge in the cementitious materials to improve the thermal insulation in the various applications. As such, it is expected that a decrease in energy costs from heating and cooling of structures would be accomplished.

\subsection{Flammability}

Most cement-based constructions are carefully designed with fire safety in mind. This is because biochar being a biomass material is prone to inferno when incorporated into buildings. Therefore, extra care has to be taken to ascertain that it is a non-flammable substance. Zhao et al. [103], reported that when slow pyrolysis is conducted on feedstock for biochar production, $80 \%$ of the biochars are less flammable. This is because fewer amount of carboxylic acids and alcohol which are highly reactive volatiles were formed on the surface. Pyrolyzing at a slow level gives much reduced surface area with effectiveness in limiting the carbon-free radicals that ultimately translates to lower flammability which would be imparted into the cement matrix by the biochar. The mechanisms responsible for this feat are the absence of $\mathrm{C}-\mathrm{C}$ covalent bonds between the aromatic carbon molecules and volatile compounds which make them inert and unreactive towards heat $[104,105]$. It is believed that besides the chemical stability of biochar, they are thermally stable materials. They are able to hinder fire propagation due to the existence of carbonaceous boundary which would delay the transportation of oxygen and fuel needed for combustion to take place.

\subsection{Internal curing agent}

The honeycomb-like pore arrangement of biochar is produced due to the escape of organic substances and volatile materials during pyrolysis. This porous surface makes it to be an excellent candidate for the internal curing of concrete because it can absorb and sustain water in its pores [106,107]. The degree of hydration can be increased when adequate water is continuously provided to the hydrating paste of Portland cement right from the mixing phase; this situation is termed internal curing. This can only be achieved by utilising a watersaturated material that could hold its contents for a considerably longer period of time. This material could play the role of a water reservoir for the hydrating cement paste to draw from when needed $[108,109]$. This is quite different from the normal curing in which after immersion of the cementitious materials in a water tank, only a few millimetres from the surface is penetrated by it. Many observations have been made from experiments conducted to show the effi- 
cacy of internal curing in improving the shrinkage, durability, cracking [110] and mechanical strength of cement-based composites especially during the later phases [111-114]. The principal role of the additional water to be supplied by the porous biochars is to make up for the vacant pore spaces of the cement matrix which were developed during the chemical shrinkage reactions at the on-set of hydration [115].

\subsection{Medium of carbon capture and storage}

Sequestration of carbon can simply be understood to mean the process of storing captured carbon in a carbon sink or reservoir; in this case, the cementitious material would play this role. By so doing, atmospheric carbon dioxide is removed leading to reduced climate change. Two distinct ways have been identified as the appropriate method of utilising biochar for carbon sequestration. Firstly, when used as an admixture in cement-based materials, most especially if mixed with other aggregates during matrix preparation, it is able to store carbon because of its stability. This is made possible by its affinity for surface pores with high fraction and non-polar compounds thereby adsorbing the $\mathrm{CO}_{2}$ [116]. In a study by Gupta [117] in which biochar was used as an admixture in the cementitious material, the influence on greenhouse emissions was evaluated. It was observed that cement mortars containing both unsaturated and saturated biochars had lower net global warming potential and reduced $\mathrm{CO}_{2}$ emission levels in comparison with mortars without biochar. Secondly, the process of production of biochar leads to a reduction of $\mathrm{CO}_{2}$ from the atmosphere because the process involves naturally degrading organic matter by a carbon-neutral system to produce a carbon-negative material. Furthermore, if such created biochar is allowed to adsorb $\mathrm{CO}_{2}$ before it is used as a cement admixture, it is capable of adsorbing $\mathrm{CO}_{2}$ of $7 \mathrm{mmol}$ per gramme of biochar which translates to a reduction of emissions of $300 \mathrm{~kg} \mathrm{CO}_{2}$-e per tonne of dry feedstock [118].

Table 2 gives a summary of the objectives of some selected studies and the effect of biochar addition on the properties tested.

\section{Influence of biochar on properties of cementitious applications}

\subsection{Physical properties}

The addition of biochar to replace Portland cement in cementitious composites is expected to result in lower fresh and hardened densities as a result of the lower specific gravity of biochar. Gupta et al. [122] reported a 7\% reduction in the fresh density of mortar incorporating rice waste biochar at $5 \%$ replacement of the Portland cement. A similar reduction in dry density was also reported when rice husk biochar was used as filler in mortar [42]. The reduction in the dry and fresh densities of cementitious composites can be associated with the lower specific gravity of the biochar which yields a corresponding reduction in the density. These observations correspond with that of Gupta et al. [38] where the incorporation of biochar at the replacement of up to $8 \%$ cement in mortar resulted in a decrease in the dry density.

\subsubsection{Workability}

The incorporation of food and wood wastes biochar into mortar mixtures had been found to reduce the workability. Results from the comprehensive investigation carried out by Gupta et al. [122] showed that the incorporation of $3 \%$ wood and food wastes biochar resulted in $13 \%$ and $10 \%$ reduction respectively, in the flow of mortar mixtures. The reduction in the workability of mortar mixtures with the incorporation of biochar as replacement of the Portland cement can be associated with the higher water absorption of the biochar which resulted in limited water available for workability. Similarly, OforiBoadu et al. [133] reported a reduction in flow when swine biochar was incorporated as a replacement of Portland cement in cement pastes. The fluidity of paste containing $2.5 \%, 5 \%$ and $10 \%$ swine biochar as replacement of Portland cement is $20 \%, 33 \%$ and $36 \%$ lower than the paste without biochar. The reduction in the flow of the paste with the incorporation of biochar was associated with the negative charges generated by the biochar's carboxyl functional groups and the higher absorption of the biochar. The high carbon content of biochar has also been reported to result in higher demand for water to achieve good workability [134]. Other studies have also shown that the porous nature of biochar results in high water absorption and consequential low workability [38,132]. Nonetheless, Sirico et al. [132] were able to use superplasticizer to overcome the detrimental effect of the incorporation of biochar on the workability of cementitious composites.

\subsubsection{Setting times}

The incorporation of biochar into mortar mixtures has been found to reduce both the initial and final setting times [135]. The reduction in the set times with the addition of biochar was attributed to the reduction in free water and filler effect of the biochar particles which results in an increase in the cohesiveness of the mixture. The reduction in setting time can also be attributed to the accelerated hydration reaction due to the incorporation of the biochar into the mortar mixtures. The incorporation of biochar into cement-based composites results in the biochar particles acting as nucleation sites for cement hydration resulting in the generation of additional hydration products (i.e. calcium silicate hydrate and calcium hydroxide). Due to the accelerated generation of these additional products, there is a corresponding reduction in the times it takes the composites to set. These findings are similar to the effects of nano and macro fillers on the setting times of cementitious composites [136-140]. Similarly, the reduction in the set times with the incorporation of biochar result in an increase of the heat of hydration [135]. The study by Gupta et al. [135] showed that the incorporation of unsaturated biochar and saturated biochar into cement paste resulted in approximately 27 and $7 \%$ increase in the peak heat flow respectively. The introduction of the biochar into the cement paste was also found to reduce the peak of the heat flow by $2 \mathrm{~h}$. This reduction in the time of the occurrence of the peak heat flow indicates the occurrence of accelerated acceleration with the introduction of biochar and a corresponding reduction in the setting time. This observation corresponds with that of Wang et al. [172,173] where the introduction of biochar into cementitious composites was found to increase the hydration heat. The increase in the hydration heat with the incorporation of biochar was attributed to the enhanced cement hydration due to the "moisture and dilution effect" $[175,176]$.

\subsubsection{Air content}

Gupta et al. [122] investigated the effect of biochar made up of wood, food and rice wastes on the air content of mortar. The findings from the study showed that the incorporation of biochar into the mortar mixtures resulted in an increase in the air content of the mixtures as shown in Fig. 1. The increase in the air content of the mortar mixtures with the introduction of biochar was attributed to the porous nature of biochar in addition to the higher content of free water available in the matrix. The presence of higher free water in fresh cementitious mixtures has been found to result in a corresponding higher air content [141].

\subsection{Mechanical properties}

\subsubsection{Compressive strength}

The incorporation of biochar made from wood wastes and food wastes into mortar mixtures was found to increase the compressive strength up to $1 \%$ replacement of the Portland cement with biochar 
Table 2

Selected studies on biochar-cement based applications.

\begin{tabular}{|c|c|c|c|c|c|c|c|}
\hline Ref. & $\begin{array}{l}\text { Objectives (in relation to } \\
\text { cementitious } \\
\text { applications) }\end{array}$ & Agro-material & $\begin{array}{l}\text { Production } \\
\text { process }\end{array}$ & $\begin{array}{l}\text { Particle } \\
\text { sizes } \\
(\mu \mathrm{m})\end{array}$ & $\begin{array}{l}\text { Properties } \\
\text { determined }\end{array}$ & $\begin{array}{l}\text { Characterisation } \\
\text { analysis }\end{array}$ & Observations \\
\hline [119] & $\begin{array}{l}\text { Enhanced mechanical } \\
\text { strength and } \\
\text { electromagnetic } \\
\text { interference shielding } \\
\text { effectiveness }\end{array}$ & $\begin{array}{l}\text { Peanut and } \\
\text { hazel nut } \\
\text { shells }\end{array}$ & $\begin{array}{l}\text { Pyrolysis at } \\
850{ }^{\circ} \mathrm{C} \text { for } \\
1 \mathrm{~h}\end{array}$ & $5-6$ & $\begin{array}{l}\text { Fracture toughness, } \\
\text { Flexural strength } \\
\text { and shielding } \\
\text { effectiveness }\end{array}$ & $\begin{array}{l}\text { Raman analyses } \\
\text { and FESEM }\end{array}$ & $\begin{array}{l}\text { Increased toughness and flexural strength, 353\% higher } \\
\text { shielding efficiency }\end{array}$ \\
\hline$[120]$ & $\begin{array}{l}\text { Influence of biochar on } \\
\text { hydration, strength, } \\
\text { ductility, shrinkage, } \\
\text { permeability }\end{array}$ & Rice husk & $\begin{array}{l}\text { Pyrolysis at } \\
500{ }^{\circ} \mathrm{C} \text { at a } \\
\text { rate of } 1{ }^{\circ} \mathrm{C} / \mathrm{s}\end{array}$ & $2-7$ & $\begin{array}{l}\text { Hydration kinetics, } \\
\text { compressive, } \\
\text { fracture toughness, } \\
\text { flexural strength, } \\
\text { water permeability }\end{array}$ & XRD, BET, MIP & $\begin{array}{l}17 \% \text { improvement in compressive strength, reduced } \\
\text { shrinkage and enhanced durability }\end{array}$ \\
\hline [121] & $\begin{array}{l}\text { Influence of three types } \\
\text { of biochar on concrete } \\
\text { strength properties }\end{array}$ & $\begin{array}{l}\text { Papermill } \\
\text { sludge } \\
\text { Rice husk } \\
\text { Poultry litter }\end{array}$ & $\begin{array}{l}\text { Slow } \\
\text { pyrolysis at } \\
450{ }^{\circ} \mathrm{C} \text { and } \\
\text { gasification } \\
\text { at } 500{ }^{\circ} \mathrm{C} \text { for } \\
20 \mathrm{~min}\end{array}$ & - & $\begin{array}{l}\text { Water absorption, } \\
\text { compressive, split } \\
\text { and flexural strength }\end{array}$ & XRF, TGA & $\begin{array}{l}0.1 \% \text { of pulp sludge and rice husk biochars enhanced } \\
\text { mechanical strength, Poultry litter improved water } \\
\text { absorption }\end{array}$ \\
\hline [122] & $\begin{array}{l}\text { Effect of food-waste } \\
\text { biochar on fresh } \\
\text { concrete properties }\end{array}$ & $\begin{array}{l}\text { Food wastes } \\
\text { from rice, } \\
\text { noodle, pasta, } \\
\text { meat and } \\
\text { vegetable }\end{array}$ & $\begin{array}{l}\text { Pyrolysis at } \\
500{ }^{\circ} \mathrm{C} \text { for } \\
45-60 \mathrm{~min}\end{array}$ & $5-200$ & $\begin{array}{l}\text { Fresh density, air } \\
\text { content, flow, } \\
\text { permeability, } \\
\text { compressive, split } \\
\text { tensile and flexural } \\
\text { strength }\end{array}$ & SEM, EDS, BET & $\begin{array}{l}\text { Inclusion of } 1-2 \% \text { wt of biochar increases air content, } \\
\text { reduced flowability, improves mechanical strength }\end{array}$ \\
\hline [123] & $\begin{array}{l}\text { Effect of grain size } \\
\text { distribution of biochar } \\
\text { on hydration, } \\
\text { permeability and } \\
\text { rheology }\end{array}$ & Saw dust & $\begin{array}{l}\text { Pyrolysis at } \\
500{ }^{\circ} \mathrm{C} \text { at } \\
10 \mathrm{C} / \mathrm{min}\end{array}$ & $0.92-100$ & $\begin{array}{l}\text { Rheology, } \\
\text { compressive and } \\
\text { flexural strength, } \\
\text { permeability }\end{array}$ & $\begin{array}{l}\text { SEM, XRD, } \\
\text { PIDS, BET, MIP }\end{array}$ & $\begin{array}{l}\text { Milled and normal biochars positively influenced } \\
\text { workability, rheology, cement hydration }\end{array}$ \\
\hline [124] & $\begin{array}{l}\text { Results of properties of } \\
\text { modified magnesium } \\
\text { phosphate cement with } \\
\text { biochar. }\end{array}$ & Wheat straw & $\begin{array}{l}\text { Pyrolysis at } \\
650^{\circ} \mathrm{C} \text { using } \\
18{ }^{\circ} \mathrm{C} / \mathrm{min}\end{array}$ & 2.05 & $\begin{array}{l}\text { Compressive and } \\
\text { flexural strength, } \\
\text { sorptivity and water } \\
\text { absorption, water } \\
\text { resistance, porosity }\end{array}$ & $\begin{array}{l}\text { XRD, SEM, EDS, } \\
\text { FTIR }\end{array}$ & $\begin{array}{l}0.5-1.5 \% \text { biochar led to } 4.1-17.3 \% \text { higher compressive } \\
\text { strength. Reduced sorptivity and water absorption from } 5.7 \\
\text { to } 4.7 \%\end{array}$ \\
\hline [125] & $\begin{array}{l}\text { Importance of biochar } \\
\text { production processes } \\
\text { and features on the } \\
\text { enhancement of } \\
\text { mechanical properties }\end{array}$ & Softwood & $\begin{array}{l}\text { Pyrolysis at } \\
680^{\circ} \text { for } \\
12 \mathrm{~min}\end{array}$ & $<6$ & $\begin{array}{l}\text { Flexural strength, } \\
\text { fracture energy }\end{array}$ & SEM & $\begin{array}{l}\text { Production parameters and features influenced the } \\
\text { formation of strong covalent carbon leading to improved } \\
\text { flexural strength and fracture energy }\end{array}$ \\
\hline [126] & $\begin{array}{l}\text { Biochar effects on } \\
\text { fracture, flexural } \\
\text { strength and ductility }\end{array}$ & Bamboo & $\begin{array}{l}\text { Pyrolyzed at } \\
850{ }^{\circ} \mathrm{C} \text { at a } \\
\text { rate of } 1{ }^{\circ} \mathrm{C} / \mathrm{s}\end{array}$ & $1-2$ & $\begin{array}{l}\text { Compressive and } \\
\text { flexural strength, } \\
\text { toughness index }\end{array}$ & SEM, EDS, TGA & $\begin{array}{l}\text { Micro-sized biochars of } 0.05-0.2 \% \text { improved flexural, } \\
\text { compressive strength and toughness }\end{array}$ \\
\hline [127] & $\begin{array}{l}\text { Relevance of chitosan to } \\
\text { development of } \\
\text { mechanical strength }\end{array}$ & $\begin{array}{l}\text { Shell fish bio- } \\
\text { waste }\end{array}$ & $\begin{array}{l}\text { Pyrolyzed at } \\
800{ }^{\circ} \mathrm{C} \text { at a } \\
\text { rate of } 5{ }^{\circ} \mathrm{C} / \mathrm{s}\end{array}$ & - & $\begin{array}{l}\text { Toughness, } \\
\text { compressive and } \\
\text { flexural strength }\end{array}$ & TGA, FTIR, SEM & $\begin{array}{l}\text { Reduced flexural strength when compared with reference } \\
\text { cement paste. Negligible compressive strength but higher } \\
\text { toughness value than the control }\end{array}$ \\
\hline [128] & $\begin{array}{l}\text { Influence of inclusion of } \\
\text { pre-soaked biochar on } \\
\text { permeability and } \\
\text { strength }\end{array}$ & $\begin{array}{l}\text { Mixed } \\
\text { sawdust }\end{array}$ & $\begin{array}{l}\text { Pyrolysis } \\
\text { within } 300- \\
500{ }^{\circ} \mathrm{C} \text { at } \\
10{ }^{\circ} \mathrm{C} / \mathrm{min}\end{array}$ & $500 \mu-5$ & $\begin{array}{l}\text { degree of hydration, } \\
\text { mass loss profile, } \\
\text { internal relative } \\
\text { humidity, } \\
\text { permeability, } \\
\text { mechanical strength }\end{array}$ & $\begin{array}{l}\text { SEM, EDS, BET, } \\
\text { PIDS }\end{array}$ & $\begin{array}{l}\text { Low mass loss, higher internal relative humidity than } \\
\text { control. Hydration degree improved by } 10-12 \% \text { resulting } \\
\text { in improved permeability and compressive strength }\end{array}$ \\
\hline$[38]$ & $\begin{array}{l}\text { Influence of biochar on } \\
\text { permeability, elastic } \\
\text { modulus, strength and } \\
\text { drying shrinkage }\end{array}$ & Wood waste & $\begin{array}{l}\text { Pyrolysis at } \\
300 \text { and } \\
500{ }^{\circ} \mathrm{C} \text { at } \\
10 \mathrm{C} / \mathrm{min}\end{array}$ & $10-18.90$ & $\begin{array}{l}\text { Compressive and } \\
\text { flexural strength, } \\
\text { drying shrinkage, } \\
\text { modulus of } \\
\text { elasticity, water } \\
\text { absorption }\end{array}$ & SEM, BET & $\begin{array}{l}1-2 \mathrm{wt} \% \text { of biochar pyrolyzed at } 300 \text { and } 500{ }^{\circ} \mathrm{C} \text { enhanced } \\
\text { compressive strength. Negligible effect on modulus of } \\
\text { elasticity, flexural strength and drying shrinkage. Inclusion } \\
\text { of } 1 \% \mathrm{w} / \mathrm{w} \text { of biochar at both temperatures resulted in } \\
58 \% \text { and } 66 \% \text { decrease in water penetration depth and } \\
\text { absorption in comparison with control. }\end{array}$ \\
\hline [129] & $\begin{array}{l}\text { Evaluation of the effect } \\
\text { of two agro-wastes on } \\
\text { mechanical properties }\end{array}$ & $\begin{array}{l}\text { Bagasse and } \\
\text { rice husk }\end{array}$ & $\begin{array}{l}\text { Pyrolysis at } \\
700{ }^{\circ} \mathrm{C} \text { for } \\
2 \mathrm{~h} \text { at } \\
10{ }^{\circ} \mathrm{C} / \mathrm{min}\end{array}$ & - & $\begin{array}{l}\text { Compressive and } \\
\text { tensile strength }\end{array}$ & SEM, XRD, BET & $\begin{array}{l}5 \text { and } 10 \% \text { contents of pretreated and un-pretreated } \\
\text { biochars caused } 36,20.4,54.8,24.4,21.1 \text { and } 23 \% \text { better } \\
\text { compressive strength than control. } 78 \% \text { increase in tensile } \\
\text { strength more than control }\end{array}$ \\
\hline [130] & $\begin{array}{l}\text { Effect of bio-mass } \\
\text { particles on mechanical } \\
\text { strength and } \\
\text { permeability }\end{array}$ & $\begin{array}{l}\text { Woody } \\
\text { biomass }\end{array}$ & $\begin{array}{l}\text { Slow } \\
\text { pyrolysis at } \\
500{ }^{\circ} \mathrm{C} \text { for } \\
1 \mathrm{~h} \text { at } \\
10{ }^{\circ} \mathrm{C} / \mathrm{min}\end{array}$ & $4-190$ & $\begin{array}{l}\text { Compressive } \\
\text { strength, water } \\
\text { sorptivity and } \\
\text { penetration, } \\
\text { influence of elevated } \\
\text { heating }\end{array}$ & SEM, XRD, BET & $\begin{array}{l}0.50 \text { and } 2 \text { wt } \% \text { of biochar improved compressive strength } \\
\text { by } 16 \% \text { and } 9 \% \text { in comparison with control. } 2 \mathrm{wt} \% \\
\text { inclusions resulted in a decrease of permeability by } 40 \% \text {. } \\
\text { Inclusion of } 1- \\
2 \mathrm{wt} \% \text { reduced thermal damage with } 20 \% \text { and } 11 \% \text { higher } \\
\text { strength more than control }\end{array}$ \\
\hline
\end{tabular}


Table 2 (continued)

\begin{tabular}{|c|c|c|c|c|c|c|c|}
\hline Ref. & $\begin{array}{l}\text { Objectives (in relation to } \\
\text { cementitious } \\
\text { applications) }\end{array}$ & Agro-material & $\begin{array}{l}\text { Production } \\
\text { process }\end{array}$ & $\begin{array}{l}\text { Particle } \\
\text { sizes } \\
(\mu \mathrm{m})\end{array}$ & $\begin{array}{l}\text { Properties } \\
\text { determined }\end{array}$ & $\begin{array}{l}\text { Characterisation } \\
\text { analysis }\end{array}$ & Observations \\
\hline [131] & $\begin{array}{l}\text { Evaluate the impact of } \\
\text { biochar on the } \mathrm{CO}_{2} \\
\text { adsorption potential of } \\
\text { cement composites and } \\
\text { the properties }\end{array}$ & Corn Stover & $\begin{array}{l}\text { Pyrolysis at } \\
550^{\circ} \mathrm{C} \text { for } \\
25 \mathrm{~min} \text { at } \\
15^{\circ} \mathrm{C} / \mathrm{min}\end{array}$ & $4.65-144$ & $\begin{array}{l}\text { Carbonation, post- } \\
\text { carbonation, } \\
\text { compressive } \\
\text { strength }\end{array}$ & $\begin{array}{l}\text { SEM, EDS, XRD, } \\
\text { FTIR }\end{array}$ & $\begin{array}{l}\text { Better } \mathrm{CO}_{2} \text { capturing after } 3 \text { days compressive strength } \\
\text { based on optimised biochar dosages at } 4 \% \text { and } 6 \% \text {. The } \\
\text { Increased content of biochar led to enhanced } 28 \text { days } \\
\text { compressive strength of un-carbonated bricks. }\end{array}$ \\
\hline [132] & $\begin{array}{l}\text { Assess the mechanical } \\
\text { performances of } \\
\text { different kinds of mortar } \\
\text { produced from varied } \\
\text { percentages of biochar }\end{array}$ & Wood chips & $\begin{array}{l}\text { Pyrolyzed } \\
\text { between } 200 \\
\text { and } 500{ }^{\circ} \mathrm{C} \\
\text { then gasified } \\
\text { at } 900{ }^{\circ} \mathrm{C}\end{array}$ & $<38$ & $\begin{array}{l}\text { Fresh properties, } \\
\text { mechanical } \\
\text { properties }\end{array}$ & $\begin{array}{l}\text { XRPD, TGA, } \\
\text { XRF, } \\
\text { GC-MS }\end{array}$ & $\begin{array}{l}\text { Increased dosages resulted in slight reduction in } \\
\text { compressive strength. A Slight increase in flexural strength } \\
\text { on the inclusion of } 1 \% \mathrm{w} / \mathrm{w} \text { of cement. }\end{array}$ \\
\hline
\end{tabular}

*Note: XRD- X-ray diffraction analysis, SEM-Scanning electron microscope, BET- Brunauer-Emmett-Teller, MIP- Mercury intrusion porosimetry, XRF- X-ray Fluorescence, TGA- Thermogravimetric analysis, EDS- Electron dispersive spectroscopy, PIDS- Polarized intensity differential scattering, FTIR- Fourier transform infrared spectroscopy, XRPD- X-Ray Powder Diffraction, GC-MS- Gas chromatography coupled to mass spectrometry.

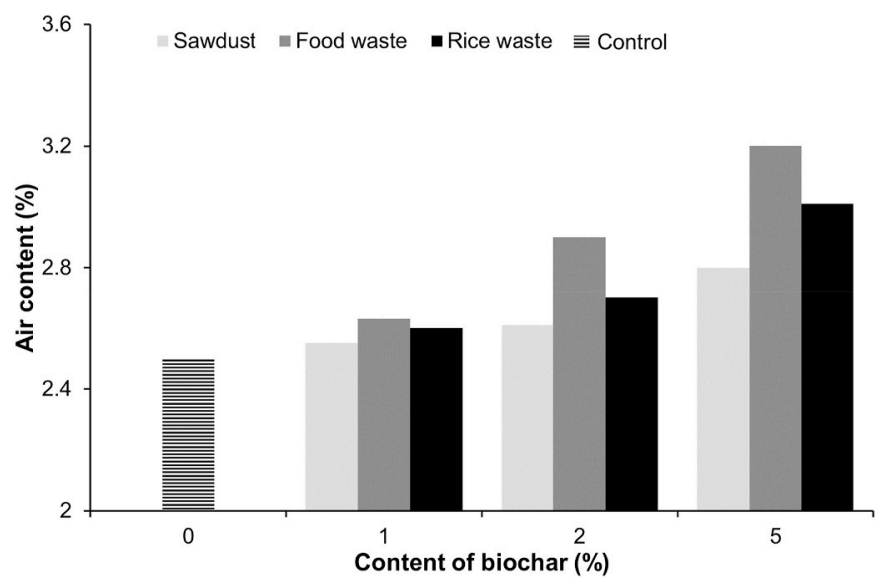

Fig. 1. Effect of biochar on air content of mortar (adapted from Ref. [122]).

[122]. However, when the biochar was incorporated at higher dosages (i.e. greater than 1\%); the compressive strength reduced. On the other hand, there was no increase in the compressive strength of mortar mixtures when biochar from rice waste was used as Portland cement replacement of up to $5 \%$. The increase in strength with the incorporation of biochar from wood and mortar waste was connected to their higher absorption capacity which results in a lower binder ratio and a corresponding densified microstructure. The pore-filling ability of the biochar particles which also results in a corresponding refinement of the microstructure can also be connected to the higher strength observed. The report from this study agree with other studies where the incorporation of biochar at lower replacement levels has been found to result in improved compressive strength [134,142,143]. Nonetheless, the compressive strength of all mortar mixtures incorporating biochar increased with age indicating the addition of the biochar does not have any detrimental effect on the progression of the hydration reaction. Akhtar and Sarmah [107] investigated the effect of three types of biochar (i.e. poultry litter, pulp and paper sludge and rice husk) on the compressive strength of concrete. The results from the study show that the incorporation of the different types of biochar as replacement of Portland cement in concrete resulted in a decrease in the compressive strength as shown in Fig. 2. The reduction in strength with the incorporation of biochar was attributed to the dilution effect of the biochar on the Portland cement which results in limited production of calcium silicate hydrate. However, as biochar possesses pozzolanic capabilities, more enhancements in compressive strength are expected in the long term. Nonetheless, it can be seen from Fig. 2 that the compressive strength of all mixtures are still above $20 \mathrm{MPa}$ regardless of the type or content of biochar. These findings indicate structural grade concrete incorporating biochar are still suitable for structural applications. Zeidabadi et al. [129] used treated

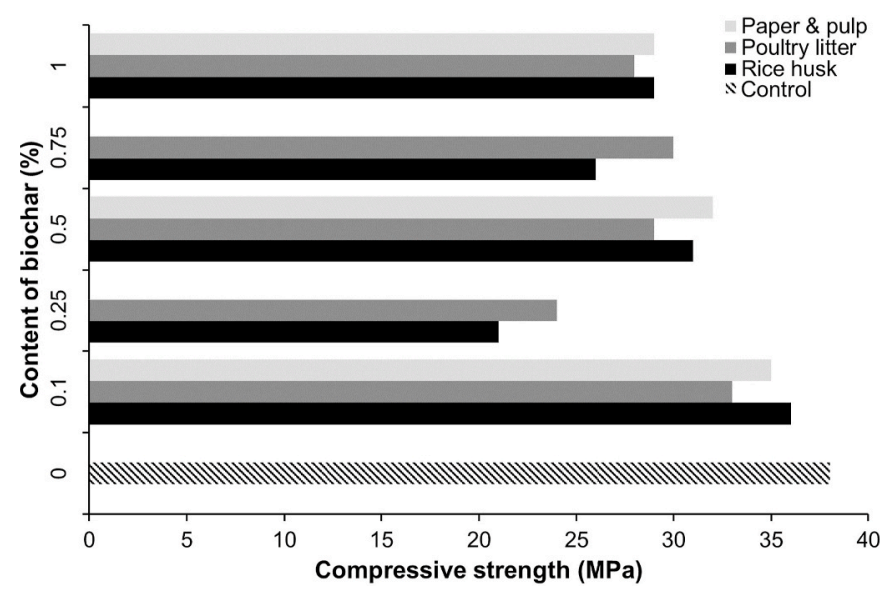

Fig. 2. Effect of various biochar on the compressive strength of concrete (adapted from Ref. [107]).

and untreated biochar from rice husk and bagasse as replacement of up to $10 \%$ cement in concrete mixtures. The results from the study indicate the use of biochar at $5 \%$ replacement of the Portland cement is the optimum regardless of the source of the biochar or treatment. Also, the chemical treatment of the biochar only enhanced the compressive strength at the optimum content (i.e. 5\%) while no significant effect was observed at a higher content. The reduction in the compressive strength at higher dosages was attributed to the higher reduction of the cement content which results in a significant decrease in the product formation. A similar observation has also been reported where the incorporation of certain dosage of materials such as bagasse ash, locust bean pod ash, wood bottom ash and rice husk ash have enhanced the compressive strength of cementitious composites whereas, a reduction in strength is exhibited at lower content [144-148]. Dixit et al. [149] incorporated various sizes of biochar as a replacement of cement in ultra-high performance concrete (UHPC). The results for the study also showed a slight reduction in the compressive strength of the concrete with the incorporation of biochar. However, the reduction in the comprehensive strength becomes more significant with an increase in the size of the biochar particles. The better performance of UHPC incorporating smaller particles of biochar can be attributed to its higher reactivity and pore-filling ability compared to that with higher particle size. These findings are in agreement with that of Restuccia and Ferro [150]. Fig. 3 presents the effect of biochar size on the compressive strength of UHPC when it was used as an $8 \%$ replacement of cement. It can be seen from Fig. 3 that more reduction in the compressive strength is evident with the increasing size of the biochar particles. Wang et al. [7] investigated the effect of biochar pyrolysis temperature on the compressive strength of carbon cured con- 


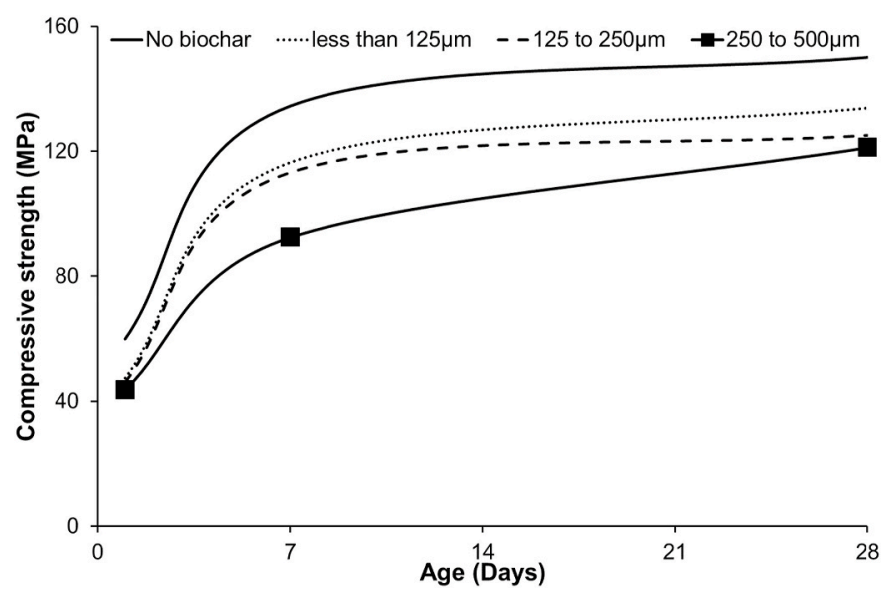

Fig. 3. Effect of biochar size on the compressive strength (adapted from Ref. [149]).

crete blocks. The outcome of the study showed that there is no significant difference in the compressive strength of blocks incorporating biochar that has undergone pyrolysis at $500{ }^{\circ} \mathrm{C}$ and $700{ }^{\circ} \mathrm{C}$ at all dosages of the biochar. Nonetheless, the compressive strength of the carbon cured blocks increased approximately by $10 \%$ when $1 \%$ of biochar was incorporated as partial replacement of the Portland cement. The enhancement of the compressive strength with the addition of $1 \%$ biochar by weight of the cement was attributed to the biochar acting as an accelerator for the hydration reaction in the presence of the carbon dioxide curing $[151,152]$. The decrease in the compressive strength at higher dosage was attributed to the brittleness of the biochar which makes it easy for cracks to form within the composites [153]. Gupta and Kua [128] recommended pre-soaking the biochar and moist curing of the corresponding composites in order to achieve an enhanced compressive strength.

The improvement in the compressive strength when biochar are pre-soaked can be attributed to the biochar acting as an internal curing agent in the composite thereby supplying additional water for the hydration process. As mentioned earlier, the ability of the biochar to act as an internal curing agent can be ascribed to its porous nature which embodied it with space to store water. The scanning electron microscope (SEM) image of biochar obtained from the pyrolysis of wood sawdust is presented in Fig. 4. It can be observed from the SEM

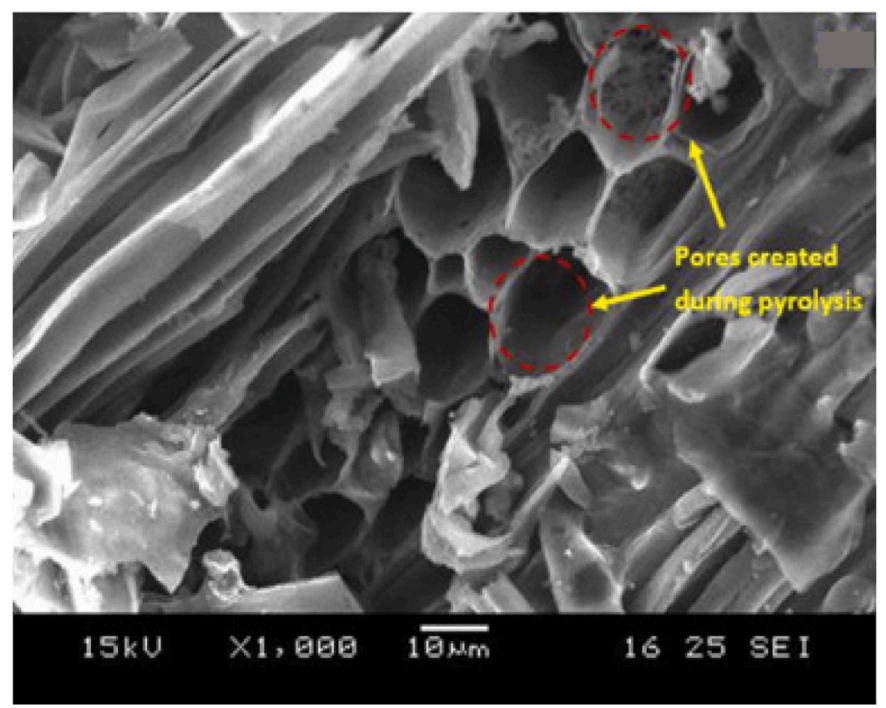

Fig. 4. SEM of biochar obtained from wood saw dust (reused with permission from Ref. [117]). image that biochar possesses a porous structure that can be formed as a result of the pyrolysis process and/or based on the source material from which the biochar is produced. Hence, the porous nature of biochar is responsible for their high absorption and ability to act as an internal curing agent when used in cementitious composites. The presence of these pores in biochar also serves as space for the formation of hydration products as seen in Fig. 5. However, it was reported by Gupta et al. [117] that poor interfacial transition zone between the biochar and the cementitious matrix is detrimental to both the mechanical and durability performance. Hence, the hydration products formed (i.e. calcium silicate hydrate and calcium hydroxide) within the pores of biochar might not contribute to the improvement of the performance of the composite.

\subsubsection{Tensile strength}

Similar to the compressive strength, the incorporation of biochar from wood wastes has been found to enhance the split tensile strength of concrete up to a dosage of $0.5 \%[42,122,130]$. The effect of biochar content on the split tensile strength is presented in Fig. 6. It can be seen from Fig. 6 that the split tensile strength of the concrete
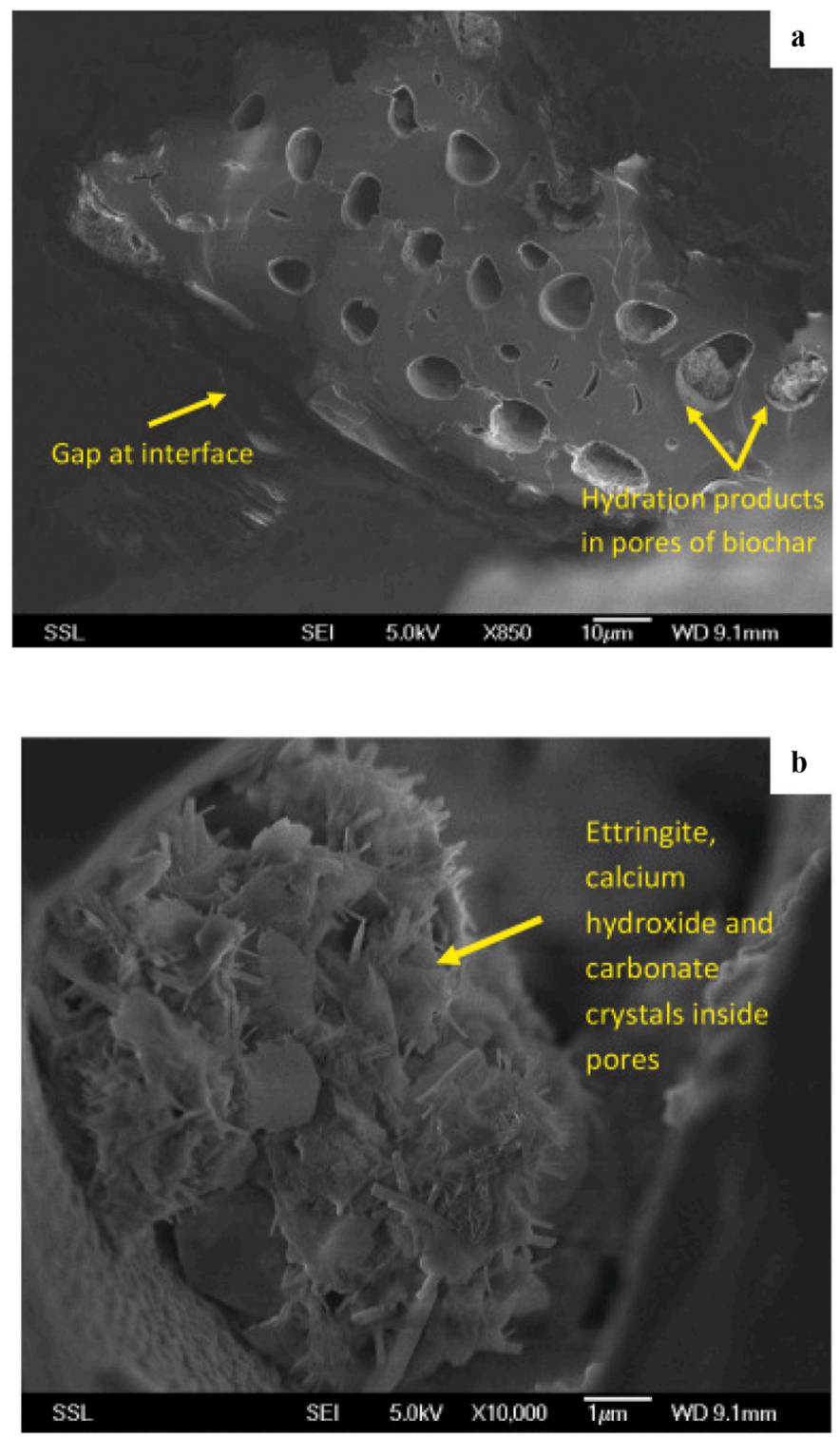

Fig. 5. Hydration product formation in biochar pores (a) external view (b) internal; view (reused with permission from Refs. [117]). 


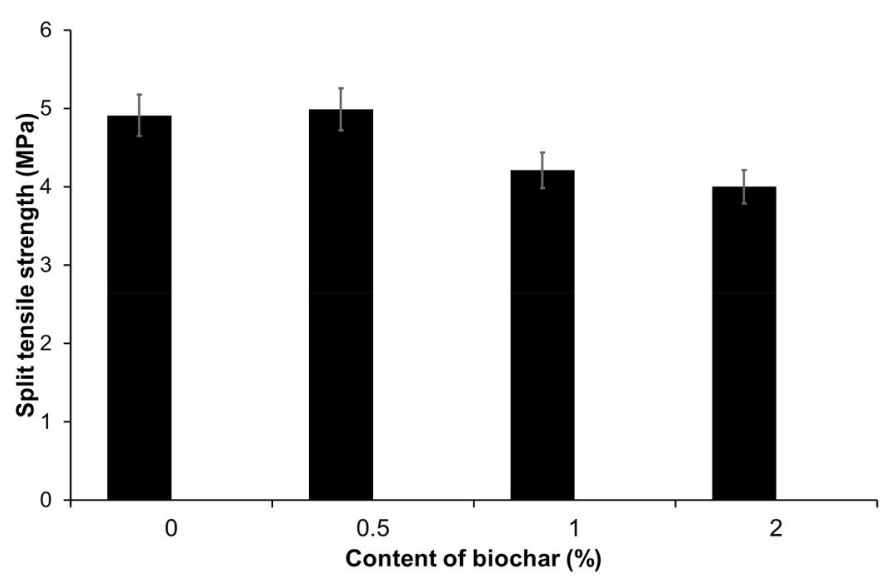

Fig. 6. Effect of biochar content on split tensile strength of concrete (adapted from Ref. [130]).

reduced at biochar content higher than $0.5 \%$ as replacement of the Portland cement. Nevertheless, biochar from sources such as wood can be used up to $2 \%$ as there is only a slight reduction in the split tensile strength compared to the control without biochar. A similar observation was reported by Akhtar and Sarmah [107] where the incorporation of biochar from three different sources was found to result in a slight decrease in the split tensile strength when the biochar was used up to $1 \%$ as replacement of the Portland cement. The reduction in the flexural strength with the incorporation of biochar was also attributed to the reduction in the amount of calcium silicate hydrate formed due to the reduction in the cement content. In contrast, Zeidabadi et al. [129] reported an increase in the tensile strength of concrete mixtures incorporation rice husk biochar up to $10 \%$ replacement of the cement. The enhancement of the tensile strength with the addition of the biochar can be associated with the possible refinement of the interfacial transition zone. This result somewhat agrees with similar studies where rice husk ash was incorporated into cementitious composites [154-157].

\subsubsection{Flexural strength}

In contrast to the compressive strength reported by Gupta et al. [122], the incorporation of $5 \%$ biochar based on food and rice wastes resulted in 14 and $18 \%$ reduction in the flexural strength respectively. The reduction in the compressive strength can be attributed to the dilution effect on the cement and also the accumulation of the biochar particles. These findings are similar to that of Khushnood et al. [119], Ahmad et al. [126] and Falliano et al. [158] where the incorporation of a higher content of biochar was reported to have a consequential effect on the flexural strength. However, in contrast to the conventional supplementary cementitious materials such as silica fume, no significant effect was found when rice husk biochar was incorporated into mortar mixtures due to its lower pozzolanic reactivity [42]. Rather the rice husk biochar acts as pore filler which results in the refinement of the microstructure. The study by Muthukrishnan et al. [43] also showed that the use of rice husk biochar can be used to slightly increase the flexural strength of mortar mixtures incorporating $20 \%$ rick husk ash as replacement of the Portland cement. This observation contradicts that of Akhtar and Sarmah [107] where the incorporation of biochar obtained from rice husk, paper and pulp sludge, and poultry litter resulted in a decrease in the compressive strength. The enhancement of the flexural strength with the incorporation of biochar observed by Muthukrishnan et al. [120] was attributed to the pore filling effect of the biochar which creates a link between the components in the concrete and increases the flexibility of the composite. The reduction of the pores in concrete has been found to result in a corresponding improvement in the flexural strength [159-161]. This observation corresponds to that of Cosentino et al.
[162] when biochar was used as a nanomaterial as shown in Fig. 7. Gupta and Kua [123] recommended moist curing for cementitious composites incorporating biochar as a slight decrease in the flexural strength was observed when mortar incorporating biochar was cured in the air. A similar study by the authors [128] also reported that moist curing the composites incorporating biochar is more effective than air curing. The effect of the type of curing on the flexural strength of mortar is presented in Fig. 8.

\subsection{Durability properties}

\subsubsection{Water absorption}

Gupta et al. [122] investigated the effect of biochar obtained from wood, food and rice wastes on the performance of mortars. The results from the study showed that the incorporation of the biochar up to a dosage of $2 \%$ resulted in a decrease in the water absorption in terms of the depth of water penetration of the mortar mixtures. The water penetration depth of mortar mixtures incorporating wood wastes at $1 \%$ and $2 \%$ replacement of the Portland cement is $64 \%$ and $57 \%$ lower than that of the control mixture with only Portland cement as the binder. The reduction in the absorption with the incorporation of biochar can be attributed to the reduction in the porosity of the mixtures which impedes the ease with which water penetrates the mortar. A correlation between the porosity and water absorption of the mortar mixtures were made and presented in Fig. 9. It can be seen from Fig. 9 that there is a good linear relationship between the water absorption and porosity of the mortar mixtures incorporating biochar.

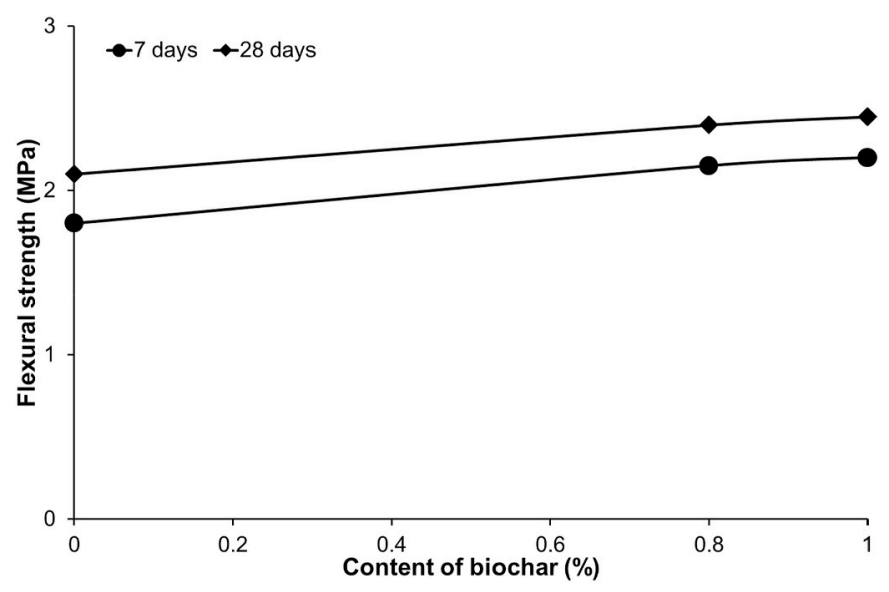

Fig. 7. Effect of biochar content on flexural strength of mortar (adapted from Ref. [162]).

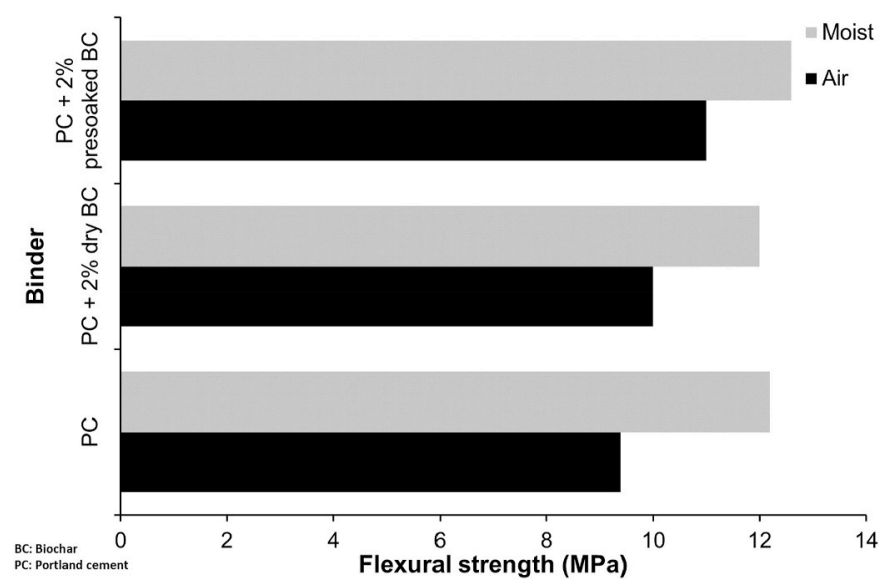

Fig. 8. Effect of curing and biochar state on flexural strength of mortar (adapted from Ref. [128]). 


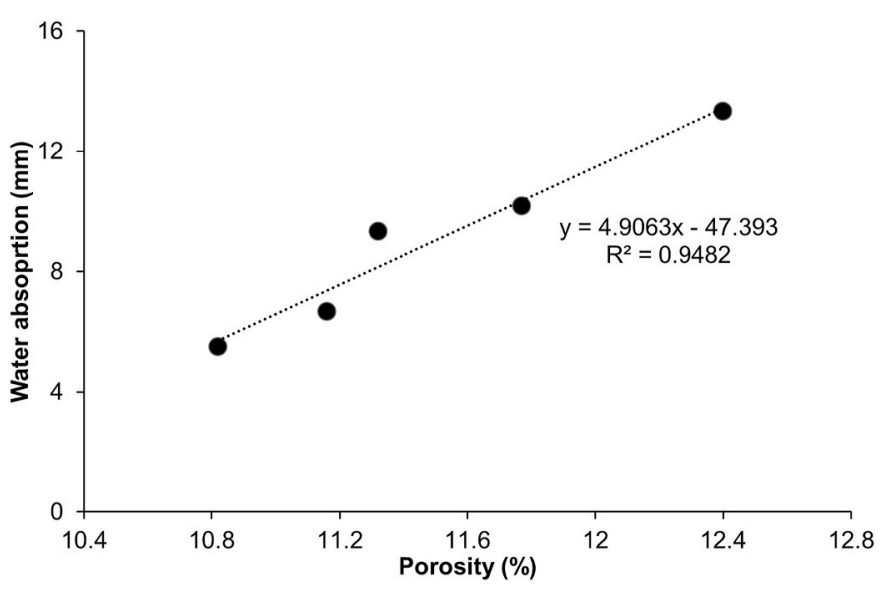

Fig. 9. Correlation between water absorption and porosity of mortar incorporating biochar (adapted from Ref. [122]).

The findings from the study also indicate that the use of biochar from wood wastes and food wastes are more effective in reducing the depth of water penetration compared with that obtained from rice wastes. A similar observation was reported by Yazicioglu [163] and Sarmah [107] where silica fume and biochar from different sources respectively, were used as a replacement of cement in concrete.

\subsubsection{Shrinkage properties}

There is limited study on the shrinkage properties of cementitious composites incorporating biochar. Nonetheless, the incorporation of biochar obtained from the pyrolysis of sawdust into the mortar as replacement of the cement was found out to increase the drying shrinkage at an early age [38]. However, at later ages, the incorporation of $1 \%$ biochar was found to reduce the drying shrinkage of mortar while the drying shrinkage of mortar containing $2 \%$ is higher than the control. These findings correspond to other studies where the use of wood ash has been reported to increase the early age drying shrinkage and reduce the later age shrinkage [164]. The effect of biochar on drying shrinkage at different ages is presented in Fig. 10. Biochar can be used as an internal curing agent to reduce the shrinkage of cementitious composites due to its stable porous structure [125,128,165,166]. Mo et al. [167] used biochar as internal curing alongside magnesium oxide to reduce autogenous shrinkage in cement pastes. Results from the study showed that the incorporation of biochar as $2 \%$ replacement of cement resulted in an approximately $16 \%$ reduction in the autogenous shrinkage. The significant reduction observed was attributed to the biochar acting as an internal curing agent as the hydration reaction progresses.

\subsubsection{Resistance to elevated temperature}

Concrete mixtures incorporating wood waste biochar up to $2 \%$ replacement of the Portland cement in the concrete mixture was found to improve the resistance of the concrete to elevated temperature [130]. Concrete mixtures incorporating biochar exhibited a mass loss of approximately $4 \%$ at a temperature of $550{ }^{\circ} \mathrm{C}$, while the concrete mixture with only PC as binder lost approximately $6 \%$ mass at the same temperature. A similar observation was also reported in the change in compressive strength and flexural strength of the concrete mixtures incorporating biochar. The flexural strength of the concrete incorporating various percentages of biochar at normal and elevated temperature is presented in Fig. 11. The enhancement of the elevated temperature resistance with the incorporation of the biochar was attributed to the higher pores in concrete incorporating biochar which prevented the accumulation of pressure within the composites. Concrete mixture incorporating biochar was also reported to have no severe cracking compared to those made with only Portland cement as a binder.

\section{Future outlook for biochar in cement-based construction}

The use of biochar in cement-based construction is emerging and the prospects are promising. Based on the current trend and research on the use of biochar in cementitious composites, future developments and applications are anticipated:

a) Regulated pyrolysis conditions: The influence of biochar on the properties of cementitious composites is strongly dependent on the thermo-chemical conversion utilised in terms of the temperature, time, the pressure used in producing the biochar. Currently, the production of biochar varies greatly which can also be associated with the varying effects reported by various studies. However, with more emerging researches on the development of biochar applications in cementitious composites, regulated pyrolysis will be developed in the nearest future.

b) Development of biochar aggregates: The porous and lightweight nature of biochar show that it can be used as lightweight aggregate in cementitious composites. A similar development has been carried out for fly ash where the particles are agglomerated and developed into lightweight aggregate. The lightweight aggregates developed from biochar can be used in cementitious composites to reduce its relieve its dead load.

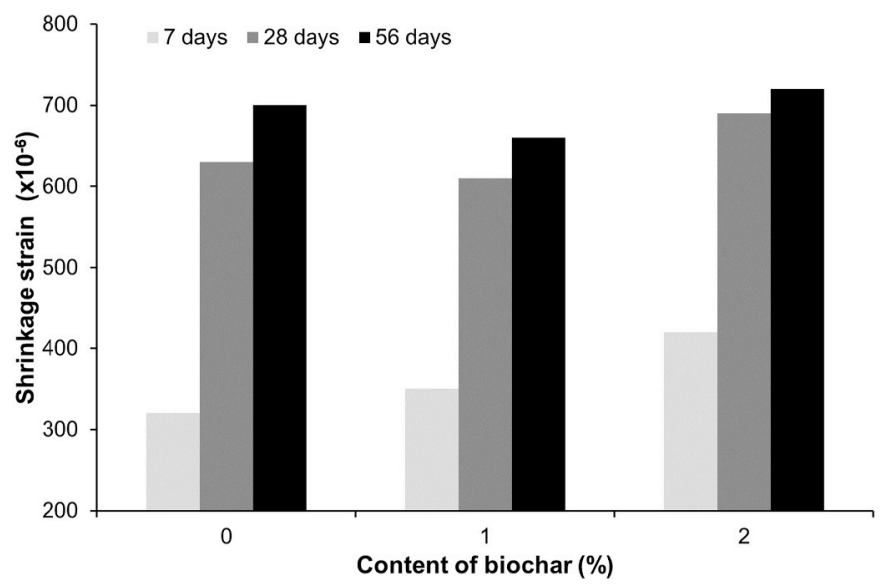

Fig. 10. Correlation between water absorption and porosity of mortar incorporating biochar (adapted from Ref. [38]).

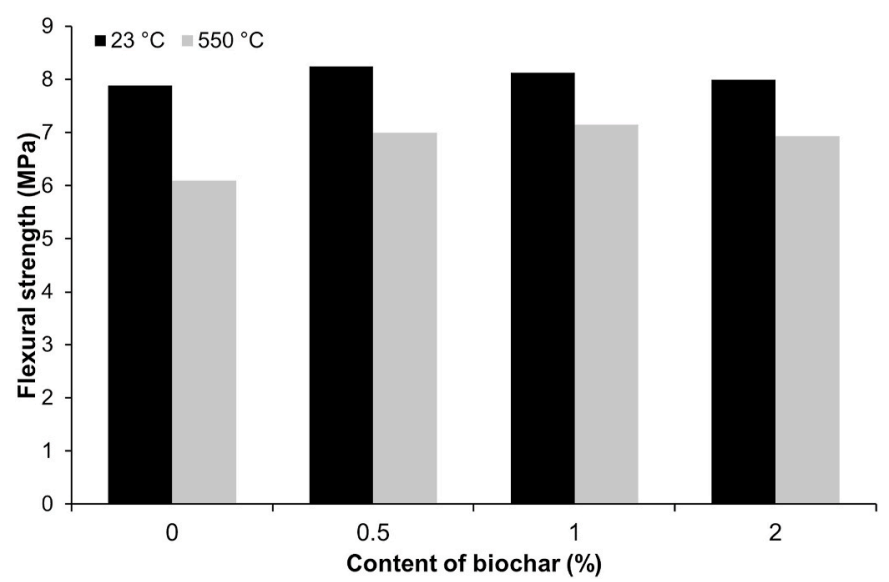

Fig. 11. Effect of biochar content on concrete resistance to elevated temperature (adapted from Ref. [42]). 
c) Development of nano biochar: Similar to the evolution of supplementary cementitious materials such as rice husk ash, silica fume, limestone; more understanding of biochar will result in the more development of nano biochars. The development of more nano biochar will open a pathway for the modification and refinement of the microstructure of cementitious composites at a nano-level. The availability of nano biochar will also create an avenue to enhance the performance of cement-based materials by replacing Portland cement with a very small volume of biochar. This will also result in Portland cement savings and a corresponding decrease in the embodied carbon of cementitious composites as a lower quantity of cement will be needed to achieve a specific performance when nano biochars are incorporated.

d) Understanding of the durability performance: Currently, most of the evaluations on the performance of cementitious composites incorporating biochar are mostly focused on mechanical performance whereas there is limited study on the corresponding durability performance. With the interest and application of cementitious composites incorporating biochar growing, more evaluation of the durability performance of such composite is anticipated. More research exploring the durability performance of cement-based materials incorporating biochar will provide more understanding of the performance of the composites and will encourage more applications of biochar in cementitious composites.

e) Use of biochar for accelerated carbonation: Currents studies on the use of biochar have shown that it can be incorporated as a green material that can be incorporated as an admixture in cementitious composites. However, biochar being a carbonaceous material can also be incorporated into cementitious composites for carbon dioxide sequestration due to its porous morphology. Hence, it is anticipated that the ongoing rapid evolution in the use of biochar in cementitious composites will result in the application of biochar to improve the carbon dioxide sequestration of construction materials.

\section{Conclusion}

There is great potential in the utilization of biochar from agricultural wastes because it has no negative impact on the environment as compared with agro-waste ashes. The adoption of biochar in cementitious materials would create opportunities for carbon sequestration from agricultural biomass wastes instead of the methane and $\mathrm{CO}_{2}$ gases that would be released during the disposal. By so doing, there will be a reduction in the impact of cement-based material production on changes in the climate since it could drastically reduce greenhouse gases. It is promising to note that if less than one percent of biochar by weight of concrete is included in concrete materials, it is realistic and possible to sequester around $0.5 \mathrm{Gt}$ (gigatonnes) of $\mathrm{CO}_{2}$ yearly by the modified concrete. This is assumed and estimated to be equivalent to roughly $20 \%$ of the yearly total emissions of $\mathrm{CO}_{2}$ produced by the cement-based industries. It is therefore imperative that such material is utilised in order to reduce the dangerous level of $\mathrm{CO}_{2}$ in the environment in which the construction and building industry is a big contributor.

Discussions presented in this paper showed that biochar can be incorporated into cementitious composites as a sustainable admixture to some properties. However, depending on the source, production method and dosage of biochar used; there is a huge variation on the influence of the biochar on the performance of the composites. Hence, it is critical to take into consideration these factors before biochar is used in cementitious composites. There is an imminent need for a comprehensive study to also be carried out to validate the individual and combined effect of the variation of these factors on the resulting performance of cementitious composites.

It is also recommended that more studies should be carried out to fully understand the physical and chemical interaction between biochar obtained from various sources and the components in cementitious composites. Limited studies have also been carried in areas such as the use of biochar as carbon dioxide sequestration material in cementitious composites. Hence, there is a need for more research, development and application of biochar to improve the sustainability of cementitious composites. Evaluation of the long-term performance of cementitious composites incorporating biochar and subjected to various environments is also important in order to encourage and propel more applications of such composites.

\section{Declaration of competing interest}

The authors declare that they have no known competing financial interests or personal relationships that could have appeared to influence the work reported in this paper.

\section{References}

[1] G. Semieniuk, V.M. Yakovenko, Historical evolution of global inequality in carbon emissions and footprints versus redistributive scenarios, J. Clean. Prod. 264 (2020).

[2] A.T. Sarmiento, M. Figueredo, M. Cobo, Techno-economic evaluation of indirect carbonation for $\mathrm{CO}_{2}$ emissions capture in cement industry: a system dynamics approach, J. Clean. Prod. 263 (2020).

[3] Y. Geng, Z. Wang, L. Shen, J. Zhao, Calculating of $\mathrm{CO}_{2}$ emission factors for Chinese cement production based on inorganic carbon and organic carbon, J. Clean. Prod. 217 (2019) 503-509.

[4] A. Karaşin, M. Doğruyol, An experimental study on strength and durability for utilization of fly ash in concrete mix, Adv. Mater. Sci. Eng. 2014 (2014) https:// doi.org/10.1155/2014/417514 417514.

[5] B. Ambedkar, J. Alex, J. Dhanalakshmi, Enhancement of mechanical properties and durability of the cement concrete by RHA as cement replacement: experiments and modeling, Construct. Build. Mater. 148 (2017) 167-175.

[6] H. Yang, H. Cui, W. Tang, Z. Li, N. Han, F. Xing, A critical review on research progress of graphene/cement based composites, Compos. Appl. Sci. Manuf. 102 (2017) 273-296.

[7] L. Wang, L. Chen, D.C. Tsang, B. Guo, J. Yang, Z. Shen, C.S. Poon, Biochar as green additives in cement-based composites with carbon dioxide curing, J. Clean. Prod. 258 (2020) 120678.

[8] L. Chen, L. Wang, D.C. Tsang, V. Mechtcherine, C.S. Poon, Efficacy of green alternatives and carbon dioxide curing in reactive magnesia cement-bonded particleboards, J. Clean. Prod. 258 (2020) 120997.

[9] T. Hemalatha, M. Mapa, N. George, S. Sasmal, Physico-chemical and mechanical characterization of high volume fly ash incorporated and engineered cement system towards developing greener cement, J. Clean. Prod. 125 (2016) 268-281.

[10] N.C. Onat, M. Kucukvar, Carbon footprint of construction industry: a global review and supply chain analysis, Renew. Sustain. Energy Rev. 124 (2020) 109783.

[11] C. Hu, Microstructure and mechanical properties of fly ash blended cement pastes, Construct. Build. Mater. 73 (2014) 618-625

[12] N. Saca, M. Georgescu, Behavior of ternary blended cements containing limestone filler and fly ash in magnesium sulfate solution at low temperature, Construct. Build. Mater. 71 (2014) 246-253.

[13] A.G.N.D. Darsanasiri, F. Matalkah, S. Ramli, K. Al-Jalode, A. Balachandra, P. Soroushian, Ternary alkali aluminosilicate cement based on rice husk ash, slag and coal fly ash, J. Build. Eng. 19 (2018) 36-41.

[14] A.V. Vidal, R.G. Araujo, J.C. Freitas, Sustainable cement slurry using rice husk ash for high temperature oil well, J. Clean. Prod. 204 (2018) 292-297.

[15] X. Cheng, Q. Dong, Y. Ma, C. Zhang, X. Gao, Y. Yu, X. Guo, Mechanical and thermal properties of aluminate cement paste with blast furnace slag at high temperatures, Construct. Build. Mater. 228 (2019) 116747.

[16] W. Song, J. Yi, H. Wu, X. He, Q. Song, J. Yin, Effect of carbon fiber on mechanical properties and dimensional stability of concrete incorporated with granulated-blast furnace slag, J. Clean. Prod. 238 (2019) 117819.

[17] J. Zhang, L. Ding, F. Li, J. Peng, Recycled aggregates from construction and demolition wastes as alternative filling materials for highway subgrades in China, J. Clean. Prod. 255 (2020) 120223.

[18] A. Akhtar, A.K. Sarmah, Construction and demolition waste generation and properties of recycled aggregate concrete: a global perspective, J. Clean. Prod. 186 (2018) 262-281.

[19] O. Canbek, S. Shakouri, S.T. Erdoğan, Laboratory production of calcium sulfoaluminate cements with high industrial waste content, Cement Concr. Compos. 106 (2020) 103475.

[20] G.B. Singh, K.V. Subramaniam, Production and characterization of low-energy Portland composite cement from post-industrial waste, J. Clean. Prod. 239 
(2019) 118024

[21] D. Woolf, J.E. Amonette, F.A. Street-Perrott, J. Lehmann, S. Joseph, Sustainable biochar to mitigate global climate change, Nat. Commun. 1 (2010) 56.

[22] D. Cuthbertson, U. Berardi, C. Briens, F. Berruti, Biochar from residual biomass as a concrete filler for improved thermal and acoustic properties, Biomass Bioenergy 120 (2019) 77-83.

[23] R. Chatterjee, B. Sajjadi, D.L. Mattern, W.Y. Chen, T. Zubatiuk, D. Leszczynska, N. Hammer, Ultrasound cavitation intensified amine functionalization: a feasible strategy for enhancing CO2 capture capacity of biochar, Fuel 225 (2018) 287298.

[24] P.D. Dissanayake, S. You, A.D. Igalavithana, Y. Xia, A. Bhatnagar, S. Gupta, Y.S. Ok, Biochar-based adsorbents for carbon dioxide capture: a critical review, Renew. Sustain. Energy Rev. 119 (2019) 109582.

[25] Y. Li, G. Ruan, A.S. Jalilov, Y.R. Tarkunde, H. Fei, J.M. Tour, Biochar as a renewable source for high-performance CO2 sorbent, Carbon 107 (2016) 344 351.

[26] H. Huang, J. Tang, K. Gao, R. He, H. Zhao, D. Werner, Characterization of KOH modified biochars from different pyrolysis temperatures and enhanced adsorption of antibiotics, RSC Adv. 7 (24) (2017) 14640-14648.

[27] J. Lehmann, S. Joseph, Biochar for environmental management: an introduction, Biochar for Environmental Management, Routledge, 2015, pp. 33-46.

[28] A. Downie, A. Crosky, P. Munroe, Physical properties of biochar, Biochar for Environmental Management, Routledge, 2012, pp. 45-64.

[29] J. Lehmann, M.C. Rillig, J. Thies, C.A. Masiello, W.C. Hockaday, D. Crowley, Biochar effects on soil biota-a review, Soil Biol. Biochem. 43 (9) (2011) 1812 1836 .

[30] K. Qian, A. Kumar, H. Zhang, D. Bellmer, R. Huhnke, Recent advances in utilization of biochar, Renew. Sustain. Energy Rev. 42 (2015) 1055-1064.

[31] M. Wang, Y. Zhu, L. Cheng, B. Andserson, X. Zhao, D. Wang, A. Ding, Review on utilization of biochar for metal-contaminated soil and sediment remediation, J. Environ. Sci. 63 (2018) 156-173.

[32] S. Dahlawi, A. Naeem, Z. Rengel, R. Naidu, Biochar application for the remediation of salt-affected soils: challenges and opportunities, Sci. Total Environ. 625 (2018) 320-335.

[33] P.K. Swain, L.M. Das, S.N. Naik, Biomass to liquid: a prospective challenge to research and development in 21st century, Renew. Sustain. Energy Rev. 15 (9) (2011) 4917-4933.

[34] A. Kumar, D.D. Jones, M.A. Hanna, Thermochemical biomass gasification: a review of the current status of the technology, Energies 2 (3) (2009) 556-581.

[35] N. Hagemann, K. Spokas, H.P. Schmidt, R. Kägi, M.A. Böhler, T.D. Bucheli, Activated carbon, biochar and charcoal: linkages and synergies across pyrogenic carbon's ABCs, Water 10 (2) (2018) 182.

[36] H. McLaughlin, An overview of the current biochar and activated carbon markets 2016 Biofuels Digest (2016)

[37] H. Marsh, F.R. Reinoso, M. Smisek, S. Cerny, Activated Carbon, Topics in Organic and General Chemistry, Elsevier Co., New York, 2006.

[38] S. Gupta, H.W. Kua, S. Dai Pang, Biochar-mortar composite: manufacturing, evaluation of physical properties and economic viability, Construct. Build. Mater. 167 (2018) 874-889.

[39] E. Sørmo, L. Silvani, G. Thune, H. Gerber, H.P. Schmidt, A.B. Smebye, G. Cornelissen, Waste timber pyrolysis in a medium-scale unit: emission budgets and biochar quality, Sci. Total Environ. 718 (2020) 137335.

[40] M.K. Awasthi, Y. Duan, S.K. Awasthi, T. Liu, Z. Zhang, Influence of bamboo biochar on mitigating greenhouse gas emissions and nitrogen loss during poultry manure composting, Bioresour. Technol. 303 (2020) 122952.

[41] J. Alchouron, C. Navarathna, H.D. Chludil, N.B. Dewage, F. Perez, C.U. Pittman Jr., T.E. Mlsna, Assessing South American Guadua chacoensis bamboo biochar and $\mathrm{Fe} 3 \mathrm{O} 4$ nanoparticle dispersed analogues for aqueous arsenic (V) remediation, Sci. Total Environ. 706 (2020) 135943.

[42] S. Gupta, H.W. Kua, Application of rice husk biochar as filler in cenosphere modified mortar: preparation, characterization and performance under elevated temperature, Construct. Build. Mater. 253 (2020) 119083.

[43] S. Muthukrishnan, S. Gupta, H.W. Kua, Application of rice husk biochar and thermally treated low silica rice husk ash to improve physical properties of cement mortar, Theor. Appl. Fract. Mech. 104 (2019) 102376.

[44] L. Wang, N.S. Bolan, D.C. Tsang, D. Hou, Green immobilization of toxic metals using alkaline enhanced rice husk biochar: effects of pyrolysis temperature and KOH concentration, Sci. Total Environ. 720 (2020) 137584.

[45] M. Lubwama, V.A. Yiga, Development of groundnut shells and bagasse briquettes as sustainable fuel sources for domestic cooking applications in Uganda, Renew. Energy 111 (2017) 532-542.

[46] I.Y. Mohammed, Y.A. Abakr, M. Musa, S. Yusup, A. Singh, F.K. Kazi, Valorization of Bambara groundnut shell via intermediate pyrolysis: products distribution and characterization, J. Clean. Prod. 139 (2016) 717-728.

[47] D. Bhaduri, A. Saha, D. Desai, H.N. Meena, Restoration of carbon and microbial activity in salt-induced soil by application of peanut shell biochar during shortterm incubation study, Chemosphere 148 (2016) 86-98.

[48] J. Yang, G. Ji, Y. Gao, W. Fu, M. Irfan, L. Mu, A. Li, High-yield and highperformance porous biochar produced from pyrolysis of peanut shell with lowdose ammonium polyphosphate for chloramphenicol adsorption, J. Clean. Prod. 264 (2020) 121516.

[49] P. Llorach-Massana, E. Lopez-Capel, J. Peña, J. Rieradevall, J.I. Montero, N. Puy, Technical feasibility and carbon footprint of biochar co-production with tomato plant residue, Waste Manag. 67 (2017) 121-130.

[50] Z. Hilioti, C.M. Michailof, D. Valasiadis, E.F. Iliopoulou, V. Koidou, A.A. Lappas, Characterization of castor plant-derived biochars and their effects as soil amendments on seedlings, Biomass Bioenergy 105 (2017) 96-106.

[51] S. Biswas, S.S. Mohapatra, U. Kumari, B.C. Meikap, T.K. Sen, Batch and continuous closed circuit semi-fluidized bed operation: removal of MB dye using sugarcane bagasse biochar and alginate composite adsorbents, J. Environ. Chem. Eng. 8 (1) (2020) 103637.

[52] A.Z. Khan, S. Khan, T. Ayaz, M.L. Brusseau, M.A. Khan, J. Nawab, S. Muhammad, Popular wood and sugarcane bagasse biochars reduced uptake of chromium and lead by lettuce from mine-contaminated soil, Environ. Pollut. 263 (2020) 114446.

[53] Y.H. Tang, S.H. Liu, D.C. Tsang, Microwave-assisted production of CO2-activated biochar from sugarcane bagasse for electrochemical desalination, J. Hazard Mater. 383 (2020) 121192

[54] M. Carrier, A.G. Hardie, Ü. Uras, J. Görgens, J.H. Knoetze, Production of char from vacuum pyrolysis of South-African sugar cane bagasse and its characterization as activated carbon and biochar, J. Anal. Appl. Pyrol. 96 (2012) 24-32.

[55] S. Xue, X. Zhang, H.H. Ngo, W. Guo, H. Wen, C. Li, C. Ma, Food waste based biochars for ammonia nitrogen removal from aqueous solutions, Bioresour. Technol. 292 (2019) 121927.

[56] A.D. Igalavithana, S.W. Choi, P.D. Dissanayake, J. Shang, C.H. Wang, X. Yang, Y.S. Ok, Gasification biochar from biowaste (food waste and wood waste) for effective CO2 adsorption, J. Hazard Mater. 391 (2019) 121147.

[57] N. Khan, P. Chowdhary, A. Ahmad, B.S. Giri, P. Chaturvedi, Hydrothermal Liquefaction of Rice Husk and Cow Dung in Mixed-Bed-Rotating Pyrolyzer and Application of Biochar for Dye Removal, Bioresource Technology, 2020, p. 123294.

[58] Q. Chen, J. Qin, P. Sun, Z. Cheng, G. Shen, Cow dung-derived engineered biochar for reclaiming phosphate from aqueous solution and its validation as slow-release fertilizer in soil-crop system, J. Clean. Prod. 172 (2018) 2009-2018.

[59] S.V. Novais, M.D.O. Zenero, J. Tronto, R.F. Conz, C.E.P. Cerri, Poultry manure and sugarcane straw biochars modified with $\mathrm{MgCl}_{2}$ for phosphorus adsorption, $\mathrm{J}$. Environ. Manag. 214 (2018) 36-44.

[60] H. Chen, S.K. Awasthi, T. Liu, Y. Duan, X. Ren, Z. Zhang, M.K. Awasthi, Effects of microbial culture and chicken manure biochar on compost maturity and greenhouse gas emissions during chicken manure composting, J. Hazard Mater. 389 (2019) 121908.

[61] J.O. Eduah, E.K. Nartey, M.K. Abekoe, H. Breuning-Madsen, M.N. Andersen, Phosphorus retention and availability in three contrasting soils amended with rice husk and corn cob biochar at varying pyrolysis temperatures, Geoderma 341 (2019) 10-17.

[62] E. Amoakwah, K.A. Frimpong, D. Okae-Anti, E. Arthur, Soil water retention, ai flow and pore structure characteristics after corn cob biochar application to a tropical sandy loam, Geoderma 307 (2017) 189-197.

[63] J. Zhang, J. Shao, Q. Jin, X. Zhang, H. Yang, Y. Chen, H. Chen, Effect of deashing on activation process and lead adsorption capacities of sludge-based biochar, Sci. Total Environ. 716 (2020) 137016.

[64] Y.F. Huang, Y.Y. Huang, P.T. Chiueh, S.L. Lo, Heterogeneous Fenton oxidation of trichloroethylene catalyzed by sewage sludge biochar: experimental study and life cycle assessment, Chemosphere 249 (2020) 126139.

[65] Y. Zhang, X. Xu, P. Zhang, L. Zhao, H. Qiu, X. Cao, Pyrolysis-temperature depended quinone and carbonyl groups as the electron accepting sites in barley grass derived biochar, Chemosphere 232 (2019) 273-280.

[66] S.D. Ferreira, I.P. Lazzarotto, J. Junges, C. Manera, M. Godinho, E. Osório, Steam gasification of biochar derived from elephant grass pyrolysis in a screw reactor, Energy Convers. Manag. 153 (2017) 163-174.

[67] M. Rizwan, Q. Lin, X. Chen, Y. Li, G. Li, X. Zhao, Y. Tian, Synthesis, characterization and application of magnetic and acid modified biochars following alkaline pretreatment of rice and cotton straws, Science of The Total Environment, 2020, p. 136532.

[68] N. Sharma, P. Kaur, D. Jain, M.S. Bhullar, In-vitro evaluation of rice straw biochars' effect on bispyribac-sodium dissipation and microbial activity in soil, Ecotoxicol. Environ. Saf. 191 (2020) 110204

[69] Z.B. Laougé, A.S. Çı̆̆gın, H. Merdun, Optimization and characterization of biooil from fast pyrolysis of Pearl Millet and Sida cordifolia L. by using response surface methodology, Fuel 274 (2020) 117842

[70] N. Priharto, F. Ronsse, G. Yildiz, H.J. Heeres, P.J. Deuss, W. Prins, Fast pyrolysis with fractional condensation of lignin-rich digested stillage from secondgeneration bioethanol production, J. Anal. Appl. Pyrol. 145 (2020) 104756.

[71] S.T. Gopakumar, Bio-oil Production through Fast Pyrolysis and Upgrading to "Green" Transportation Fuels, A Dissertation: Doctor of Philosophy-the Graduate Faculty of Auburn University, Alabama, 2012196.

[72] T. Yuan, W. He, G. Yin, S. Xu, Comparison of bio-chars formation derived from fast and slow pyrolysis of walnut shell, Fuel 261 (2020) 116450.

[73] J. Park, Y. Lee, C. Ryu, Y.K. Park, Slow pyrolysis of rice straw: analysis of products properties, carbon and energy yields, Bioresour. Technol. 155 (2014) 63-70.

[74] B. Zhao, D. O'Connor, J. Zhang, T. Peng, Z. Shen, D.C. Tsang, D. Hou, Effect of pyrolysis temperature, heating rate, and residence time on rapeseed stem derived biochar, J. Clean. Prod. 174 (2018) 977-987.

[75] M.J. Antal Jr., W.S. Mok, G. Varhegyi, T. Szekely, Review of methods for improving the yield of charcoal from biomass. Energy \& Fuels AND Demirbas, A. (2004). Effects of temperature and particle size on bio-char yield from pyrolysis of agricultural residues, J. Anal. Appl. Pyrol. 4 (3) (1990) 221-225.

[76] Y. Chhiti, M. Kemiha, Thermal conversion of biomass, pyrolysis and gasification, Int. J. Eng. Sci. 2 (3) (2013) 75-85.

[77] A.V. Bridgwater, P. Carson, M. Coulson, A comparison of fast and slow pyrolysis 
liquids from mallee, Int. J. Global Energy Issues 27 (2) (2007) 204

[78] R.C. Saxena, D. Seal, S. Kumar, H.B. Goyal, Thermo-chemical routes for hydrogen rich gas from biomass: a review, Renew. Sustain. Energy Rev. 12 (7) (2008) 1909-1927.

[79] T. Sharma, Biochar and Other Properties Resulting from the Gasification and Combustion of Biomass with Different Components PhD (Doctor of Philosophy) thesis University of Iowa, 2019, https://doi.org/10.17077/etd.8n2a-6nhz.

[80] K.R. Khalilpour (Ed.), Polygeneration with Polystorage: for Chemical and Energy Hubs, Academic Press, 2018.

[81] K. Zhang, J. Chang, Y. Guan, H. Chen, Y. Yang, J. Jiang, Lignocellulosic biomass gasification technology in China, Renew. Energy 49 (2013) 175-184.

[82] P. Parthasarathy, K.S. Narayanan, Hydrogen production from steam gasification of biomass: influence of process parameters on hydrogen yield-a review, Renew. Energy 66 (2014) 570-579.

[83] Y. Matsumura, Hydrothermal gasification of biomass, Recent Advances in Thermo-Chemical Conversion of Biomass, Elsevier, 2015, pp. 251-267.

[84] A. Kruse, Hydrothermal biomass gasification, J. Supercrit. Fluids 47 (3) (2009) 391-399.

[85] L. Haselbach, A. Thomas, Carbon sequestration in concrete sidewalk samples, Construct. Build. Mater. 54 (2014) 47-52.

[86] Y. Shao, M.S. Mirza, X. Wu, CO2 sequestration using calcium-silicate concrete, Can. J. Civ. Eng. 33 (6) (2006) 776-784.

[87] S. Mindess, High Performance Concrete: Recent Developments in Material Design. Materiały International Advanced Course "Design and Application of High Performance Cement Based Materials", IPPT, Warszawa, 2003.

[88] S. Gupta, H.W. Kua, Factors determining the potential of biochar as a carbon capturing and sequestering construction material: critical review, J. Mater. Civ. Eng. 29 (9) (2017) 04017086.

[89] R. Mrad, G. Chehab, Mechanical and microstructure properties of biochar-based mortar: an internal curing agent for PCC, Sustainability 11 (9) (2019) 2491.

[90] S.M. Ndirangu, Y. Liu, K. Xu, S. Song, Risk evaluation of pyrolyzed biochar from multiple wastes, J. Chem. 2019 AB (2019) 2019 4506314, https://doi.org/10. 1155/2019/4506314.

[91] J.M. Novak, W.J. Busscher, D.L. Laird, M. Ahmedna, D.W. Watts, M.A. Niandou, Impact of biochar amendment on fertility of a southeastern coastal plain soil, Soil Sci. 174 (2) (2009) 105-112.

[92] M.J. Gundale, T.H. DeLuca, Temperature and source material influence ecological attributes of ponderosa pine and Douglas-fir charcoal, For. Ecol. Manag. 231 (1-3) (2006) 86-93.

[93] B. Chen, D. Zhou, L. Zhu, X. Shen, Sorption characteristics and mechanisms of organic contaminant to carbonaceous biosorbents in aqueous solution, Sci. China, Ser. B: Chemistry 51 (5) (2008) 464.

[94] Z. Khanmohammadi, M. Afyuni, M.R. Mosaddeghi, Effect of pyrolysis temperature on chemical and physical properties of sewage sludge biochar, Waste Manag. Res. 33 (3) (2015) 275-283.

[95] H.S. Kambo, A. Dutta, A comparative review of biochar and hydrochar in terms of production, physico-chemical properties and applications, Renew. Sustain. Energy Rev. 45 (2015) 359-378.

[96] C.E. Brewer, Biochar Characterization and Engineering Ph.D. Thesis Iowa State University, Ames, IA, USA, 2012.

[97] E. Ganjian, The Relationship between Porosity and Thermal Conductivity of Concrete, Doctoral dissertation, University of Leeds, 1990.

[98] R. Askari, S. Taheri, S.H. Hejazi, Thermal conductivity of granular porous media: a pore scale modeling approach, AIP Adv. 5 (9) (2015) 097106.

[99] M.I. Bird, P.L. Ascough, Isotopes in pyrogenic carbon: a review, Org. Geochem. 42 (12) (2012) 1529-1539.

[100] D. Cuthbertson, U. Berardi, C. Briens, F. Berruti, Biochar from residual biomass as a concrete filler for improved thermal and acoustic properties, Biomass Bioenergy 120 (2019) 77-83.

[101] H. Lee, S. Yang, S. Wi, S. Kim, Thermal transfer behavior of biochar-natural inorganic clay composite for building envelope insulation, Construct. Build. Mater. 223 (2019) 668-678.

[102] T.S. Yun, Y.J. Jeong, T.S. Han, K.S. Youm, Evaluation of thermal conductivity for thermally insulated concretes, Energy Build. 61 (2013) 125-132.

[103] M.Y. Zhao, A. Enders, J. Lehmann, Short-and long-term flammability of biochars, Biomass Bioenergy 69 (2014) 183-191.

[104] O. Das, N.K. Kim, A.K. Sarmah, D. Bhattacharyya, Development of waste based biochar/wool hybrid biocomposites: flammability characteristics and mechanical properties, J. Clean. Prod. 144 (2017) 79-89.

[105] O. Das, D. Bhattacharyya, D. Hui, K.T. Lau, Mechanical and flammability characterisations of biochar/polypropylene biocomposites, Compos. B Eng. 106 (2016) 120-128.

[106] R. Mrad, G. Chehab, Mechanical and microstructure properties of biochar-based mortar: an internal curing agent for PCC, Sustainability 11 (9) (2019) 2491.

[107] A. Akhtar, A.K. Sarmah, Novel biochar-concrete composites: manufacturing, characterization and evaluation of the mechanical properties, Sci. Total Environ. 616 (2018) 408-416.

[108] R. Henkensiefken, J. Castro, H. Kim, D. Bentz, J. Weiss, Internal curing improves concrete performance throughout its life, Concrete InFocus 8 (5) (2009) 22-30.

[109] H. Famili, M. Khodadad Saryazdi, T. Parhizkar, Internal curing of high strength self consolidating concrete by saturated lightweight aggregate-effects on material properties, Int. J. Civ. Eng. 10 (3) (2012) 210-221.

[110] H.E. Lam, Effects of Internal Curing Methods on Restrained Shrinkage and Permeability Master's Thesis University of Toronto, Toronto, ON, Canada, 2005.

[111] D.P. Bentz, P.E. Stutzman, Internal Curing and Microstructure of High Performance Mortars. ACI SP-256, Internal Curing of High Performance
Concretes, Laboratory and Field Experiences, 2008, pp. 81-90.

[112] P. Lura, O.M. Jensen, S.I. Igarashi, Experimental observation of internal water curing of concrete, Mater. Struct. 40 (2) (2007) 211-220.

[113] X. Sun, B. Zhang, Q. Dai, X. Yu, Investigation of internal curing effects on microstructure and permeability of interface transition zones in cement mortar with SEM imaging, transport simulation and hydration modeling techniques, Construct. Build. Mater. 76 (2015) 366-379.

[114] H. Al-Khaiat, M.N. Haque, Effect of initial curing on early strength and physical properties of a lightweight concrete, Cement Concr. Res. 28 (6) (1998) 859-866.

[115] P. Lura, Autogenous Deformation and Internal Curing of Concrete, Publlication of Deftl University Press, 2003 Accessed online on 27/04/2020 from http:// resolver.tudelft.nl/uuid:1a1efc2d-a638-4787-b543-5bd643a39a4b.

[116] K.G. Roberts, B.A. Gloy, S. Joseph, N.R. Scott, J. Lehmann, Life cycle assessmen of biochar systems: estimating the energetic, economic, and climate change potential, Environ. Sci. Technol. 44 (2) (2010) 827-833.

[117] S. Gupta, H.W. Kua, C.Y. Low, Use of biochar as carbon sequestering additive in cement mortar, Cement Concr. Compos. 87 (2018) 110-129.

[118] H. Wei, S. Deng, B. Hu, Z. Chen, B. Wang, J. Huang, G. Yu, Granular bambooderived activated carbon for high $\mathrm{CO}_{2}$ adsorption: the dominant role of narrow micropores, ChemSusChem 5 (12) (2012) 2354-2360.

[119] R.A. Khushnood, S. Ahmad, L. Restuccia, C. Spoto, P. Jagdale, J.M. Tulliani, G. A. Ferro, Carbonized nano/microparticles for enhanced mechanical properties and electromagnetic interference shielding of cementitious materials, Front. Struct. Civ. Eng. 10 (2) (2016) 209-213.

[120] S. Muthukrishnan, S. Gupta, H.W. Kua, Application of rice husk biochar and thermally treated low silica rice husk ash to improve physical properties of cement mortar, Theor. Appl. Fract. Mech. 104 (2019) 102376.

[121] A. Akhtar, A.K. Sarmah, Novel biochar-concrete composites: manufacturing, characterization and evaluation of the mechanical properties, Sci. Total Environ. 616 (2018) 408-416.

[122] S. Gupta, H.W. Kua, H.J. Koh, Application of biochar from food and wood waste as green admixture for cement mortar, Sci. Total Environ. 619 (2018) 419-435.

[123] S. Gupta, H.W. Kua, Carbonaceous micro-filler for cement: effect of particle size and dosage of biochar on fresh and hardened properties of cement mortar, Sci. Total Environ. 662 (2019) 952-962.

[124] M.R. Ahmad, B. Chen, H. Duan, Improvement effect of pyrolyzed agro-food biochar on the properties of magnesium phosphate cement, Sci. Total Environ. 718 (2020) 137422

[125] I. Cosentino, L. Restuccia, G.A. Ferro, J.M. Tulliani, Type of materials, pyrolysis conditions, carbon content and size dimensions: the parameters that influence the mechanical properties of biochar cement-based composites, Theor. Appl. Fract. Mech. 103 (2019) 102261.

[126] S. Ahmad, R.A. Khushnood, P. Jagdale, J.M. Tulliani, G.A. Ferro, High performance self-consolidating cementitious composites by using micro carbonized bamboo particles, Mater. Des. 76 (2015) 223-229.

[127] R. Nisticò, L. Lavagna, D. Versaci, P. Ivanchenko, P. Benzi, Chitosan and its Char as Fillers in Cement-Base Composites: A Case Study, Boletín de la Sociedad Española de Cerámica y Vidrio, 2019.

[128] S. Gupta, H.W. Kua, Effect of water entrainment by pre-soaked biochar particles on strength and permeability of cement mortar, Construct. Build. Mater. 159 (2018) 107-125

[129] Z.A. Zeidabadi, S. Bakhtiari, H. Abbaslou, A.R. Ghanizadeh, Synthesis, characterization and evaluation of biochar from agricultural waste biomass for use in building materials, Construct. Build. Mater. 181 (2018) 301-308.

[130] S. Gupta, H.W. Kua, S. Dai Pang, Effect of biochar on mechanical and permeability properties of concrete exposed to elevated temperature, Construct. Build. Mater. 234 (2020) 117338.

[131] S. Praneeth, R. Guo, T. Wang, B.K. Dubey, A.K. Sarmah, Accelerated carbonation of biochar reinforced cement-fly ash composites: enhancing and sequestering CO2 in building materials, Construct. Build. Mater. 244 (2020) 118363.

[132] A. Sirico, P. Bernardi, B. Belletti, A. Malcevschi, E. Dalcanale, I. Domenichelli, E. Moretti, Mechanical characterization of cement-based materials containing biochar from gasification, Construct. Build. Mater. 246 (2020) 118490.

[133] A.N. Ofori-Boadu, R. Kelley, F. Aryeetey, E. Fini, P. Akangah, The influence of swine-waste bio-char on the early-age characteristics of cement pastes, Int. J. Eng. Res. Appl. 7 (6) (2017) 1-7.

[134] W.C. Choi, H.D. Yun, J.Y. Lee, Mechanical properties of mortar containing biochar from pyrolysis, J. Korea Inst. Struct. Maint. Insp. 16 (3) (2012) 67-74.

[135] S. Gupta, H.W. Kua, C.Y. Low, Use of biochar as carbon sequestering additive in cement mortar, Cement Concr. Compos. 87 (2018) 110-129.

[136] M. Bouasker, P. Mounanga, P. Turcry, A. Loukili, A. Khelidj, Chemical shrinkage of cement pastes and mortars at very early age: effect of limestone filler and granular inclusions, Cement Concr. Compos. 30 (1) (2008) 13-22.

[137] A.M. Poppe, G. De Schutter, Cement hydration in the presence of high filler contents, Cement Concr. Res. 35 (12) (2005) 2290-2299.

[138] M.H. Zhang, J. Islam, Use of nano-silica to reduce setting time and increase early strength of concretes with high volumes of fly ash or slag, Construct. Build. Mater. 29 (2012) 573-580.

[139] M. Ltifi, A. Guefrech, P. Mounanga, A. Khelidj, Experimental study of the effect of addition of nano-silica on the behaviour of cement mortars, Procedia Eng. 10 (2011) 900-905

[140] J. Chen, S.C. Kou, C.S. Poon, Hydration and properties of nano-TiO2 blended cement composites, Cement Concr. Compos. 34 (5) (2012) 642-649.

[141] S. Mindess, D. Darwin, J.F. Young, Concrete, 2nd ed., Prentice Hall, Pearson Education, Inc. Upper Saddle River, NJ 07458, U.S.A, 2003.

[142] L. Restuccia, A. Reggio, G.A. Ferro, R. Kamranirad, Fractal analysis of crack 
paths into innovative carbon-based cementitious composites, Theor. Appl. Fract. Mech. 90 (2017) 133-141.

[143] M. Cyr, P. Lawrence, E. Ringot, Mineral admixtures in mortars: quantification of the physical effects of inert materials on short-term hydration, Cement Concr. Res. 35 (4) (2005) 719-730.

[144] J. James, M.S. Rao, Reactivity of rice husk ash, Cement Concr. Res. 16 (3) (1986) 296-302

[145] B.A. Akinyemi, C. Dai, Development of banana fibers and wood bottom ash modified cement mortars, Construct. Build. Mater. 241 (2020) 118041.

[146] A. Adesina, Use of rice husk in concrete: review of mechanical properties, J. Curr. Constr. Issues (2018) 1-22.

[147] G.C. Cordeiro, R.D. Toledo Filho, L.M. Tavares, E.D.M.R. Fairbairn, Ultrafine grinding of sugar cane bagasse ash for application as pozzolanic admixture in concrete, Cement Concr. Res. 39 (2) (2009) 110-115.

[148] T.D. Akpenpuun, B. Akinyemi, O. Olawale, O.J. Aladegboye, O.I. Adesina, Mechanical and structural characteristics of cement mortars blended with locust bean pod ash, Agric. Eng. Int CIGR J. 21 (4) (2019) 48-55.

[149] A. Dixit, S. Gupta, S. Dai Pang, H.W. Kua, Waste Valorisation using biochar for cement replacement and internal curing in ultra-high performance concrete, $\mathrm{J}$. Clean. Prod. 238 (2019) 117876.

[150] L. Restuccia, G.A. Ferro, Promising low cost carbon-based materials to improve strength and toughness in cement composites, Construct. Build. Mater. 126 (2016) 1034-1043.

[151] X. Pan, C. Shi, N. Farzadnia, X. Hu, J. Zheng, Properties and microstructure of $\mathrm{CO}_{2}$ surface treated cement mortars with subsequent lime-saturated water curing, Cement Concr. Compos. 99 (2019) 89-99.

[152] J.G. Jang, H.K. Lee, Microstructural densification and $\mathrm{CO}_{2}$ uptake promoted by the carbonation curing of belite-rich Portland cement, Cement Concr. Res. 82 (2016) 50-57.

[153] T.C. Odimegwu, I. Zakaria, M.M. Abood, C.B.K. Nketsiah, M. Ahmad, Review on different beneficial ways of applying alum sludge in a sustainable disposal manner, Civil Eng. J. 4 (9) (2018) 2230-2241.

[154] Y.J. Patel, N. Shah, Development of self-compacting geopolymer concrete as a sustainable construction material, Sustain. Environ. Res. 28 (6) (2018) 412-421.

[155] K. Ganesan, K. Rajagopal, K. Thangavel, Evaluation of bagasse ash as supplementary cementitious material, Cement Concr. Compos. 29 (6) (2007) 515-524.

[156] V. Sata, C. Jaturapitakkul, K. Kiattikomol, Influence of pozzolan from various by-product materials on mechanical properties of high-strength concrete, Construct. Build. Mater. 21 (7) (2007) 1589-1598.

[157] H.T. Le, S.T. Nguyen, H.M. Ludwig, A study on high performance fine-grained concrete containing rice husk ash, Int. J. Concr. Struct. Mater. 8 (4) (2014) 301 307.

[158] D. Falliano, D. De Domenico, A. Sciarrone, G. Ricciardi, L. Restuccia, G. Ferro, E. Gugliandolo, Influence of biochar additions on the fracture behavior of foamed concrete, Frat. Ed. Integrità Strutt. 14 (51) (2020) 189-198.

[159] D. Snoeck, D. Schaubroeck, P. Dubruel, N. De Belie, Effect of high amounts of superabsorbent polymers and additional water on the workability, microstructure and strength of mortars with a water-to-cement ratio of 0.50, Construct. Build. Mater. 72 (2014) 148-157.

[160] P.O. Awoyera, A. Adesina, R. Gobinath, Role of recycling fine materials as filler for improving performance of concrete-a review, Aust. J. Civ. Eng. 17 (2) (2019) 85-95.

[161] A. Adesina, P. Awoyera, Overview of trends in the application of waste materials in self-compacting concrete production, SN Appl. Sci. 1 (9) (2019) 962

[162] I. Cosentino, L. Restuccia, G.A. Ferro, J.M. Tulliani, Influence of pyrolysis parameters on the efficiency of the biochar as nanoparticles into cement-based composites, Procedia Structural Integrity 13 (2018) 2132-2136.

[163] N. Bozkurt, S. Yazicioglu, Strength and Capillary Water Absorption of Lightweight Concrete under Different Curing Conditions, 2010.

[164] T.R. Naik, R.N. Kraus, Demonstration of manufacturing technology for concrete and clsm utilizing wood ash from Wisconsin, n.d, accessed May 1, 2020 http:// www.cbu-uwm.info/abstracts/04-551.pdf.

[165] E.M. Batista, J. Shultz, T.T. Matos, M.R. Fornari, T.M. Ferreira, B. Szpoganicz, A S. Mangrich, Effect of surface and porosity of biochar on water holding capacity aiming indirectly at preservation of the Amazon biome, Sci. Rep. 8 (1) (2018) 19.

[166] Z. Liu, B. Dugan, C.A. Masiello, H.M. Gonnermann, Biochar particle size, shape, and porosity act together to influence soil water properties, PLoS One 12 (6) (2017).

[167] L. Mo, J. Fang, B. Huang, A. Wang, M. Deng, Combined effects of biochar and $\mathrm{MgO}$ expansive additive on the autogenous shrinkage, internal relative humidity and compressive strength of cement pastes, Construct. Build. Mater. 229 (2019) 116877.

[168] B. Akinyemi, C. Dai, Development of banana fibers and wood bottom ash modified cement mortars, Construct. Build. Mater. 241 (2020) 118041.

[169] A. Sivakrishna, A. Adesina, O. Awoyera, K. Kumar, Green concrete: a review of recent developments, Mater. Today: Proc. 27 (2020) 54-58.

[170] B. Akinyemi, T. Omoniyi, O. Elemile, O. Arowofila, Innovative husk-crete building materials from rice Chaff and modified cement mortars, Acta Technol. Agric. 11 (2020) 67-72.

[171] K. Roberts, B. Gloy, S. Joseph, N. Scott, J. Lehmann, Life cycle assessment of biochar systems: estimating the energetic, economic, and climate change potential, Environ. Sci. Technol. 44 (2009) 827-833.

[172] L. Wang, L. Chen, C. Tsang, H. Kua, J. Yang, Y. Ok, C. Poon, Biochar as green additives in cement-based composites with carbon dioxide curing, J. Clean. Prod. 258 (2020) 103348

[173] L. Wang, L. Chen, C. Tsang, H. Kua, J. Yang, Y. Ok, C. Poon, The roles of biochar as green admixture for sediment-based construction products, Cement Concr. Compos. 104 (2019) 120678

[174] L. Wang, D. Cho, C. Tsang, X. Cao, D. Hou, Z. Shen, C. Poon, Green Remediation of as and $\mathrm{Pb}$ Contaminated Soil Using Cement-free Clay-Based Stabilization/ solidification, vol. 126, 2019, pp. 336-345.

[175] S. Fang, D. Tsang, F. Zhou, W. Zhang, R. Qui, Stabilization of cationic and anionic metal species in contaminated soils using sludge-derived biochar, Chemosphere 149 (2016) 363-371.

[176] Huang, W., Kazemi-Kamyab, H., Sun, W., and Scrivener, K. Effect of cement substitution by limestone on the hydration and microstructural development of ultra-high-performance concrete (UHPC). Cement Concr. Compos., 77, 86-101. 